\title{
The Regulation of Consumer Financial Products: An Introductory Essay with Four Case Studies
}

\section{Citation}

Campbell, John Y., Howell E. Jackson, Brigitte C. Madrian, and Peter Tufano. 2010. The Regulation of Consumer Financial Products: An Introductory Essay with Four Case Studies. HKS Faculty Research Working Paper Series RWP10-040, John F. Kennedy School of Government, Harvard University.

\section{Published Version}

http://web.hks.harvard.edu/publications/workingpapers/citation.aspx?Publd=7419

\section{Permanent link}

http://nrs.harvard.edu/urn-3:HUL.InstRepos:4450128

\section{Terms of Use}

This article was downloaded from Harvard University's DASH repository, and is made available under the terms and conditions applicable to Other Posted Material, as set forth at http:// nrs.harvard.edu/urn-3:HUL.InstRepos:dash.current.terms-of-use\#LAA

\section{Share Your Story}

The Harvard community has made this article openly available.

Please share how this access benefits you. Submit a story.

\section{Accessibility}


The Regulation of Consumer

Financial Products: An

Introductory Essay with Four

Case Studies

Faculty Research Working Paper Series

\section{John Y. Campbell}

Harvard University

\section{Howell E. Jackson}

Harvard Law School

\section{Brigitte C. Madrian}

Harvard Kennedy School

\section{Peter Tufano}

Harvard Business School

\section{September 2010 RWP10-040}

The views expressed in the HKS Faculty Research Working Paper Series are those of the author(s) and do not necessarily reflect those of the John F. Kennedy School of Government or of Harvard University. Faculty Research Working Papers have not undergone formal review and approval. Such papers are included in this series to elicit feedback and to encourage debate on important public policy challenges. Copyright belongs to the author(s). Papers may be downloaded for personal use only. 
D03, D1, D14, D18, D91, G2, G21, G23, G28, K23, P46

\title{
The Regulation of Consumer Financial Products: An Introductory Essay with Four Case Studies
}

by

\author{
John Y. Campbell, Harvard University \\ Howell E. Jackson, Harvard Law School \\ Brigitte C. Madrian, Harvard Kennedy School \\ Peter Tufano, Harvard Business School
}

July 27, 2010

\begin{abstract}
The recent financial crisis has led many to question how well businesses deliver consumer financial services and how well regulatory institutions address problems in consumer financial markets. In response, the Obama administration proposed a new agency to oversee consumer financial services, and the recently enacted Dodd-Frank Wall Street Reform and Consumer Protection Act embraced the Administration's proposal by creating the Bureau of Consumer Financial Protection. Other regulatory reforms have been advanced, and in some cases adopted, in recent years, at both the federal and state level. In this paper, we provide an overview of consumer financial markets, detailing the purposes they serve, the extent to which they suffer from market failures or other deficiencies, and the structure of our current system of regulation. To illustrate our analytical framework, we present case studies on retirement savings, residential mortgages, payday lending, and mutual funds. We conclude with a series of observations on the limits of government intervention, suggestions about how to measure whether government intervention is successful, and potentially fruitful lines of future research and data collection.
\end{abstract}


The authors have benefitted from helpful comments from David Autor, Sendhil Mullainathan, Tim Taylor, and participants in the Harvard Joint Center for Housing Study's February 2010 Symposium: Moving Forward - The Future of Consumer Credit and Mortgage Finance. 


\section{Introduction}

Recent economic events have focused attention on the financial decisions made by consumers and the practices of retail financial institutions. Many argue that consumer confusion in the increasingly complex mortgage market contributed to the subprime market meltdown of 2007, which in turn triggered the global financial crisis. More generally, there is widespread concern that consumers are being asked to take increasing responsibility for their own financial wellbeing in retirement, and that many households are ill prepared for this task.

While consumer financial regulation has always been an important element of public policy, it has received much greater emphasis recently. One of the first actions of the $111^{\text {th }}$ Congress under the new Obama Administration was the passage of the Credit Card Accountability, Responsibility, and Disclosure (CARD) Act of 2009, which banned retroactive fee changes and required consumers to opt-in to over-the-limit fees, among other features. ${ }^{1}$ A far more comprehensive approach to the protection of consumers was embodied in the Obama Administration's proposals to create a new regulatory body to oversee consumer financial services. This proposal was a centerpiece of the Treasury Department's Financial Regulatory Reform plan and is included in both House and Senate financial reform bills. The objective of this reform is spelled out in the original Treasury white paper on the topic:

"To rebuild trust in our markets, we need strong and consistent regulation and supervision of consumer financial services and investment markets. We should base this oversight not on speculation or abstract models, but on actual data about how people make financial decisions. We must promote transparency, simplicity, fairness, accountability, and access. We propose:

- A new Consumer Financial Protection Agency to protect consumers across the financial sector from unfair, deceptive, and abusive practices.

- Stronger regulations to improve the transparency, fairness, and appropriateness of consumer and investor products and services.

- A level playing field and higher standards for providers of consumer financial products and services, whether or not they are part of a bank."2

The Administration's proposal was incorporated into title $\mathrm{X}$ of the Dodd-Frank Wall Street Reform and Consumer Protection Act, which establishes a new Bureau of Consumer Financial Protection. The Bureau is designed to serve as the primary federal agency responsible for consumer financial protection for credit, savings and payment services. A wide range of other federal agencies and state authorities with retain important supervising roles with respect to other areas of consumer finance.

\footnotetext{
${ }^{1}$ For details, see http://www.whitehouse.gov/the_press_office/Fact-Sheet-Reforms-to-Protect-American-CreditCard-Holders/ (visited 4/25/10).

${ }^{2}$ See http://www.financialstability.gov/docs/regs/FinalReport_web.pdf (visited 4/25/2010).
} 
Our goal in this paper is to explain the economic basis for consumer financial regulation. We begin by briefly describing the functions, scope and scale of consumer financial markets. We then survey the justifications for government intervention into consumer financial markets. While regulation in this field is often framed in terms "transparency, simplicity, fairness, accountability, and access," we relate these concepts to various market failures that may impede economic efficiency or create unacceptable distributional outcomes. We then review the structure of consumer financial regulation in the United States and the most common regulatory mechanisms that are used to police consumer financial markets.

To illustrate how many of the themes in the paper apply to consumer financial markets, we present case studies on retirement savings, residential mortgages, mutual funds, and payday lending. Finally, we outline the types of future research (and their data requirements) that would be most useful in informing how to optimally regulate consumer financial markets. By making clear the economic foundations of consumer financial regulation, we hope to better define the metrics for evaluating the success or failure of regulatory reform. In short, without knowing the goals for reform, it is impossible to assess whether we have succeeded in creating a "better" financial system.

\section{A Brief Overview of Consumer Financial Markets}

\section{A. Functions of the consumer financial system}

While consumer finance could be defined by reference to specific institutions (banks or insurance companies) or products (deposits or life insurance), we follow Merton and Bodie (1995) and Tufano (2009) in positing that financial systems can be best understood in terms of the functions they perform. These functions include ${ }^{3}$ :

- Payments. The financial system must provide a mechanism for the transfer of money and payments for goods and services. In the consumer sector, the payments function includes cash, checks, debit cards, credit cards, pre-paid cards, postal and private money orders, wire transfers, remittances, barter, online funds transfer tools like PayPal, Automated Clearing House $(\mathrm{ACH})$ transactions, payroll systems, and the infrastructure which supports all of these activities. These products are delivered by many different organizations, including the government (e.g., money and post offices), banking institutions, non-banks (e.g., check cashing stores), data processors, online businesses, and others.

- Managing risk. There are many mechanisms to mitigate the financial risks faced by consumers, such as insurance (health, life, property and casualty, disability), financial products (e.g., put options to protect against portfolio declines), precautionary savings, social networks, and government welfare programs. The organizations that perform this function range from the family and local community to insurance companies and government disaster relief plans. From the perspective of businesses which serve

\footnotetext{
${ }^{3}$ In prior work, advice and resolution of conflicts of interest have also been included as financial functions. In this paper, we characterize these activities as solutions to problems of asymmetric information or incomplete contracts.
} 
consumers, risks are managed through credit scoring models and credit risk practices, as well as by assembling a diversified portfolio or securing insurance against default.

- Borrowing - advancing funds from the future to today. The function of household credit encompasses short-term unsecured borrowing (e.g., credit and charge cards, banking overdraft protection, and payday loans), longer-term unsecured borrowing (e.g., student loans, person to person lending), and secured borrowing (e.g., auto loans, mortgage loans, and margin loans). The provision of credit takes place in the formal sector, the informal sector (friends and family), and through various hybrid organizations (e.g., person to person lending websites). In addition to explicit borrowing, implicit borrowing is built into various derivative products, including options and forwards, as well as commercial structures (e.g., rent-to-own schemes).

- Saving/Investing-advancing funds from today until a later date. Investing or savings functions are embodied in a host of products and services, including bank products (savings accounts and CDs), mutual funds, variable annuities, workplace retirement programs, and Social Security. These products vary based on the intended time horizon, level and type of risk borne by the investor, tax treatment, and other factors.

\section{B. The economics of consumer financial businesses}

To understand the regulation of consumer financial markets, it is useful to get some idea of the economics of this sector, which is at the same time both very large and quite small. In aggregate, households held \$68.2 trillion in assets at year-end 2009 with 33.8\% (\$23.1 trillion) of these funds in tangible assets (mostly real estate) and $\$ 45.1$ trillion in financial assets. ${ }^{4}$ On the other side of the balance sheet, households held $\$ 14.0$ trillion in liabilities, mostly home mortgages (\$10.3 trillion) and consumer credit (\$2.5 trillion, primarily in credit cards). In sheer size, the household sector dominates the corporate sector. Total corporate debt, for example, is only about half the size of household debt (\$7.2 trillion).

Balance sheet numbers alone belie the full magnitude of the consumer finance sector. Visa and MasterCard, for instance, report combined annual transaction volume exceeding \$6 trillion. ${ }^{5}$ While easy to focus on such aggregates, this sum is comprised of a staggering number of small transactions: over 70 billion a year. Similarly, while total mutual fund industry assets exceed \$10 trillion, the ICI reports that the median investor has $\$ 100,000$ in fund assets spread across four different accounts. ${ }^{6}$ Even with these comparatively large accounts (nearly twice

\footnotetext{
${ }^{4}$ See Federal Reserve Statistical Release Z.1: Flow of Funds Account of the United States (Mar. 11, 2010) (http://www.federalreserve.gov/releases/z1/Current/z1.pdf, visited 5/4/2010), This information refers to households and non-profit organizations, as the two are considered a single sector in the Flow of Fund calculations. As nonprofits account for only five to seven percent of assets and liabilities, these figures are largely reflective of the household sector (Teplin, 2001).

${ }^{5}$ See http://www.corporate.visa.com/av/pdf/Visa_Inc_Overview.pdf (visited 5/4/2010, data as of March 2008) and http://www.mastercard.com/us/company/en/newsroom/annual_report/MasterCard_2007AR.pdf (visited 5/4/2010, data as of December 2007). Figures represent all card transactions worldwide.

${ }^{6}$ See http://www.ici.org/pdf/rpt_profile09.pdf (visited 5/4/2010).
} 
median family income in America), the fund industry has to deal with a large number of small accounts.

Tables 1 and 2 give a finer breakdown of the asset holdings and liabilities of U.S. families in 2007 by type of asset or liability, for all families and by position in the income distribution. These tables highlight various features of consumer financial markets. First, as noted above, the median account balances for many of the cells in the bottom panels of Table 1 and 2 are indeed relatively small. Second, although transaction accounts are the most widely held asset (92\%), one-quarter of families in the bottom decile of the income distribution do not have such accounts. These families, the so-called unbanked, rely on other mechanisms for payment services. ${ }^{7}$ Third, asset and liability holdings vary considerably by position in the income distribution, particularly for direct holdings of equities and retirement savings accounts and for mortgage debt. This disparate incidence strikes some as problematic and has led some policymakers to call for expanded access to some types of financial services.

The small account and transaction sizes have several implications for retail financial services and their regulation. First, the cost of customer acquisition or asset gathering is large relative to the cost of producing actual services. Bergstresser, Chalmers and Tufano (2009) find that distribution costs account for $39 \%$ of all charges paid by mutual fund investors. Second, because of the sheer number of transactions, the level of contact with and information about customers may be limited. This makes full-information contracting nearly impossible and gives rise to low-cost automated solutions like credit scoring models. Third, economies of scale and scope are often more complex than in simple micro-economics models. For example, the marginal cost of a single additional account might be nearly zero, but adding many accounts might necessitate more call center operators, or even a new call center, with lumpy additions to cost. Finally, because of the joint nature of production, establishing product or activity costs can be challenging. All of these considerations should factor into assessing the costs and benefits of financial regulation.

\section{The Need for Consumer Financial Regulation}

Consumer advocates often make the case for consumer financial regulation on distributional grounds, arguing that unregulated markets disadvantage lower income households. This is an important consideration, but we begin by first assessing the potential inefficiencies of consumer financial markets that might call for regulation before turning to distributional considerations.

There are several features of consumer financial markets that can lead to inefficient outcomes that may justify government intervention. Most fundamentally, financial markets often involve both time and uncertainty. Many financial transactions require initial payments from one party to another, offset by payments in the opposite direction in the future that are explicitly state-contingent or implicitly subject to the risk of complete or partial default. During the life of

\footnotetext{
${ }^{7}$ Another substantial group of households (17\%) maintain transaction accounts but are considered under-banked because they also rely on alternative financial services, such as payday lenders and pawn shops (Federal Deposit Insurance Corporation, 2009).
} 
a financial transaction, the two parties involved have conflicting interests and often have asymmetric information, leading to a rich variety of problems that have been studied by contract and information theorists. It is difficult to structure contracts that handle every possible contingency that may arise during the life of a transaction, and this contractual incompleteness can create problems.

Another set of problems arise because consumers may not behave as time-consistent, rational utility maximizers. They may, for example, have present-biased preferences, in which decisions each period favor present consumption even though the consumer would display greater patience if enabled to commit to a future consumption plan. Just as importantly, consumers may lack the cognitive capacity to optimize their financial situation, even if presented with all the information that in principle is required to do so. It is unusually difficult to learn how to optimize in certain financial markets. Many financial transactions are infrequently undertaken and have delayed outcomes that are subject to large random shocks, so personal experience is slow to accumulate and is contaminated by noise. Social learning is encumbered first by the fact that many financial shocks are common, so that averaging outcomes across neighbors may not eliminate noise, and second by the rapid pace of financial innovation, which reduces the relevance of older cohorts' experiences. A strong social taboo on discussing personal financial matters in certain cultures further reduces the effectiveness of social learning (Zelizer, 1994).

In order to understand the many sources of inefficiency in consumer financial markets, it is helpful to start with the traditional taxonomy of conditions that may result in market failure even with fully rational consumers. ${ }^{8}$ We then relate these to the failures that may be caused by present-biased preferences or cognitive limitations. Finally, we consider distributional issues.

\section{A. Traditional Economic Justifications for Consumer Financial Regulation}

Enforcement of financial contracts. Many consumer financial transactions span long time horizons or entail the transfer of wealth over considerable geographic distance. The temporal aspect of financial products gives firms the ability to engage in moral hazard in a way that may impede market efficiency. In markets such as those for retirement savings or life insurance, performance occurs over a long period of time, well after consumers and firms enter into a contractual commitment. Consumers are unlikely to be able to engage in continuous monitoring, and reputation may be insufficient to discipline firms who are tempted to expropriate their clients' wealth. In this case, mandatory capital requirements and other forms of on-going supervision may be needed to ensure the development of well-functioning markets. Such regulation is valuable not only for consumers, but also for firms, as it provides a commitment device that enables them to win business that would otherwise be unavailable.

Externalities. Individual financial behavior may affect others in ways that are not reflected in market prices. Positive externalities from human capital accumulation and home

\footnotetext{
${ }^{8}$ Earlier papers have presented more limited taxonomies of the economic justifications for consumer financial regulation. Hynes and Posner (2002) offer an overview of potential market failures in consumer credit transactions. Carlin and Gervais (2009) and Inderst and Ottaviani (2009) present models dealing with financial advice. Bar-Gill (2008) and Wright (2007) provide differing perspectives on the behavioral economics of consumer contracts.
} 
ownership have been used to justify government subsidies to student loans and home mortgages. Conversely, foreclosures have social costs that are not taken into account by mortgage borrowers and lenders. ${ }^{9}$ More generally, correlated investment strategies may increase the systemic risk in financial markets and thus warrant supervisory intervention.

Search costs and market power. Price dispersion is a feature of many retail markets. It can be sustained by the existence of search costs which make some consumers willing to pay higher prices than they might find elsewhere. These search costs give retailers a degree of market power, allowing them to charge prices above marginal cost. One example in the financial arena is S\&P 500 index funds-providers charge a wide range of fees for an essentially identical product (Hortacsu and Syverson, 2004). Search costs can be addressed by providing information on market prices (e.g., Medicare Part D prescription drug plan decision aids), by standardizing information provision (e.g., requiring firms to quote interest rates as an annualized percentage rate, or mandating uniform disclosure of fees and past returns in mutual fund prospectuses), or through direct regulation of prices. More general responses to market power include limitations on the scale or scope of financial service firms or enhanced anti-trust requirements.

Information as a public good. To make informed decisions, consumers often need information about financial products that they cannot efficiently generate themselves and for which joint production with other consumers is not easily coordinated. Often the financial provider will be the most efficient supplier of this information. Disclosure requirementsmandates that the firm produce and disseminate certain types of information-are an example of interventions that address this type of market failure. Anti-fraud rules backed through judicial enforcement mechanisms serve a similar purpose, though traditionally were limited to intentional affirmative misrepresentations.

Other information failures. Consumer financial markets can also fail because of information asymmetries. Indeed, consumer finance provides the textbook cases of information problems: the underprovision of insurance and consumer credit as a result of adverse selection and moral hazard. The regulatory responses to this type of market failure include mandating the purchase of insurance (e.g., auto insurance), public provision of universal insurance programs such as social security to mitigate adverse selection, and subsidizing private insurance purchases through the tax system.

In some cases, the government "solution" to ill-functioning private insurance markets may itself create moral hazard that might justify further intervention. For example, the social safety net might encourage individuals to assume excessive financial risks which will result in some suffering large financial losses that qualify them for public aid. Government can mitigate this moral hazard through restrictions on financial risk-taking, such as limits on employer stock holdings in retirement accounts.

Finally, the complexity of many consumer financial products generate both information

\footnotetext{
${ }^{9}$ Campbell, Giglio, and Pathak (2009) present evidence that foreclosures lower the prices of nearby houses. The effect is extremely local and is stronger in low-priced neighborhoods, suggesting that the transmission mechanism may be vandalism or neighborhood deterioration.
} 
asymmetries (firms know more about the products than do consumers) and transaction costs that make it difficult for even the most sophisticated individuals to comparison shop. This complexity may suppress the development of robust markets for certain consumer financial products. In these circumstances, constraints on the variation in product terms may actually improve social welfare, albeit at the cost of inhibiting consumer choice.

\section{B. Justifications Based on Cognitive Limitations of Consumers}

In addition to the traditional market failures described above, recent research in behavioral economics has highlighted the potential for inefficient market outcomes that result from consumers' cognitive limitations. The division between these cognitive limitations and the neoclassical justifications for governmental intervention can admittedly blur at times, but there are important differences in their analytical frameworks and policy implications. Neoclassical justifications locate market failures in the structure of markets and the incentives faced by individuals and firms, whereas behavioral justifications locate the failures in the mental processes of individuals. ${ }^{10}$ Beyond this difference in orientation, the behavioral economics research often suggests different kinds of governmental interventions, in particular, measures designed more to correct biases and reorient consumer decision-making rather than to proscribe business activities or dictate the terms of exchange (Thaler and Sunstein, 2008).

Present-biased preferences. Present-biased preferences (Strotz, 1955; Laibson, 1997) generate a type of externality in which the decisions of an individual today negatively impact the welfare of the same individual in the future in a way that is not internally consistent and that implies future regret. This type of negative externality is sometimes referred to as an "internality." Present-biased preferences have been used to explain behaviors as diverse as failing to save for retirement and taking up smoking. The proposed policy responses to such preferences are to constrain today's self from taking actions that would be too detrimental to the future self, and could include limiting early access to retirement saving or taxing consumption of cigarettes.

Cognitive limitations and financial illiteracy. Recent research has documented a pervasive lack of basic financial literacy (e.g., Lusardi and Mitchell, 2006, 2007; Lusardi, Mitchell and Curto, 2010; Lusardi and Tufano, 2009). For example, consider the answers to a short set of financial literacy questions first added to the Health and Retirement Study in 2004 and subsequently incorporated into several other national and international surveys. Table 3 lists these questions and the answers of respondents to two such surveys. Among the older Health and Retirement Study Respondents, only 56\% correctly answer the first two questions, and only 24\% get all three questions correct (Lusardi and Mitchell, 2006). The younger NLSY respondents fare even worse, with only $46 \%$ answering the first two questions correctly, and $27 \%$ getting all three questions right (Lusardi, Mitchell and Curto, 2010).

A lack of financial literacy need not be problematic if, as Milton Friedman suggested, consumers learn to behave optimally through trial and error, much as a pool player need not have

\footnotetext{
${ }^{10}$ The possibility that firms might exploit these biases to enhance profits creates a further rationale for government intervention (Barr et al., 2008).
} 
any knowledge of physics in order to play pool well (Freidman, 1953). But there is growing evidence that consumers make avoidable financial mistakes with non-trivial financial consequences (Agarwal et al., 2009; Campbell, 2006; Choi et al., forthcoming). Moreover, these mistakes are more common among consumers with lower levels of education and income (Calvet, Campbell, and Sodini, 2007 and 2009) and who are less financially literate (Kimball and Shumway, 2007). While cognitive ability is difficult to measure in a way that can be matched to financial data, there is some evidence that consumers who perform better on cognitive tests make better financial decisions in laboratory experiments (Benjamin, Brown, and Shapiro, 2006) and earn higher returns on their equity portfolios later in life (Grinblatt, Keloharju, and Linnainmaa, 2009).

If consumers cannot maximize their own welfare, there is no reason to believe that competitive markets will be efficient. A social planner can in principle achieve better outcomes, judged using the true welfare function of consumers, than a free market that responds to the biased decisions that financially illiterate consumers make. This is true both because financially illiterate consumers may pick inappropriate financial products, and because real resources may be wasted as firms seek to persuade consumers to purchase excessively expensive, and hence profitable, products. Such rent-seeking behavior creates deadweight loss.

In practice, of course, it is difficult for regulators to know the true objectives of households. But in certain cases outcomes may be improved by regulations on market conduct that reflect the presumed judgment of what most consumers would want, were they fully informed and well advised. This logic underpins the libertarian paternalism or "nudges" discussed at length by Thaler and Sunstein (2008). Other examples include mandatory capital requirements and portfolio restrictions on depository institutions, prior approval regimes regarding the integrity of personnel in many areas of the financial services industry, and the many mandatory restraints on the structure of mutual funds and other financial firms.

Trust. Consumers with cognitive limitations may use rules of thumb to guide their behavior. One such rule of thumb is to avoid the use of certain financial products altogether (Christelis, Jappelli, and Padula, 2009; Cole and Shastry, 2009). This has been interpreted as a lack of trust in the financial system (Guiso, Sapienza, and Zingales, 2008). Since lack of financial market participation can be a serious mistake, there is a case for regulation to improve consumer trust through such things as restrictions on insider trading, suitability and fiduciary requirements, and other measures that convey a sense of strong supervisory oversight. ${ }^{11}$ There is evidence that mutual fund markets with stronger levels of investor protection are larger than those with lower levels of protection (Khorana, Servaes and Tufano, 2005), perhaps working through this channel of trust.

Self-knowledge. Markets may work poorly if consumers do not correctly understand their own time-inconsistent preferences or cognitive limitations, in other words, if they lack selfknowledge. For example, consumers may choose a bank account with "free" checking, underestimating the extent to which they will pay penalty fees for overdrawing their accounts in

11 Interventions to promote trust are analytically similar to traditional economic justifications of regulation as means to facilitate long-duration financial contracts, which were discussed earlier. 
the future. Such lack of self-knowledge leads to several problems. First, naïve consumers may purchase too many bank services because they underestimate the total cost to them. Second, banks compete away the excess profits they obtain through overdraft fees by keeping base charges low on checking accounts. This implies that naïve consumers cross-subsidize sophisticated consumers who don't overdraw their accounts. Products that allocate costs more equally across naïve and sophisticated consumers cannot be successfully brought to market as sophisticated consumers find it attractive to retain the cross-subsidies embedded in existing products. Nor is it profitable for firms to educate naïve consumers, because educated consumers become sophisticated and then demand fewer high-cost financial services. Finally, there are troubling distributional implications because naïve consumers are likely to have lower incomes than sophisticated consumers. This "shrouded equilibrium" has been modeled by Gabaix and Laibson (2006). Campbell (2006) presents evidence that similar phenomena are important in mortgage markets.

\section{Distributional Considerations and Consumer Financial Regulation}

Even when unregulated markets are efficient, they may generate unacceptable distributional outcomes. While in principle this can be addressed by social welfare programs and progressive income taxation, distributional considerations also motivate some consumer financial regulation. As noted earlier, consumers with high search costs are likely to pay higher prices in unregulated markets. In some contexts, search costs are higher for those with a high value of time and are likely to be positively correlated with income. Aguiar and Hurst (2007), for example, show that middle-aged consumers pay higher prices than do retired consumers because they spend less time shopping. In consumer financial markets, however, search costs may be more correlated with cognitive ability and financial experience than with the value of time. Individuals of limited cognitive ability or financial expertise may have higher search costs because they lack easy access to information or the capacity to process it, and thus may pay high prices for financial products even though they have low incomes. Distributional considerations thus strengthen the case for measures to reduce search costs or to limit the ability of firms to exercise market power over consumers with high search costs.

Distributional concerns also motivate regulatory restrictions on the ability of financial firms to vary pricing of certain products, even when there is variation in the underlying cost of delivering services. Current legislation about certain credit products is predicated on the logic that low-income consumers should not pay more than high-income consumers for credit. In some auto insurance markets, state laws prohibit setting insurance premiums on the basis of geography or age. In the area of consumer credit, various federal statutes, including the Equal Credit Opportunity Act and the Federal Housing Act, prohibit price discrimination based on race and various other individual characteristics. And, in the case of depository institutions, the Community Reinvestment Act of 1977 requires firms to serve the credit needs of low and moderate income borrowers. Other forms of this logic, framed around universality, have motivated measures to subsidize access to financial markets by lower-income consumers.

\section{The Structure and Mechanisms of Consumer Financial Regulation}


In the United States, a complex system of government agencies, statutory structures, and implementing regulations exists to regulate consumer financial markets. Both federal and state agencies play important roles as do the courts and various private bodies. The mechanisms of regulatory interventions-that is, the regulatory requirements and supervisory techniques-are also multi-faceted. In this section of the paper we offer an overview of this legal regime.

\section{A. The Regulatory Structure of Consumer Financial Markets}

The core of our system of financial regulation is organized around the three traditional financial sectors of deposit-taking, trading in securities or other capital market instruments, and insurance (Jackson and Symons, 1999). Before entering these lines of business, firms must usually obtain an operating charter or license from the appropriate authorities and then comply with required regulations, submit periodic reports, and undergo regular examinations to ensure compliance with regulatory standards. One important function of financial regulators is to enjoin the unauthorized provision of these regulated financial services.

While in other developed countries the oversight of the financial services industry has been moving toward more consolidated operations, the United States retains an idiosyncratically fragmented system of financial supervisory oversight (Government Accountability Office, 2009). Depository institutions, for example, can have either federal or state charters. The federal government has three chartering agencies (the Comptroller of the Currency for commercial banks, the Office of Thrift Supervision for thrifts, and the National Credit Union Administration for credit unions) as well as two other supervisory bodies (the Federal Deposit Insurance Corporation and the Federal Reserve Board) which share jurisdiction over state-chartered banks. This fragmented system of chartering can promote beneficial regulatory competition among government agencies, but can also lead to regulatory arbitrage and lax oversight.

In the area of capital markets, there are two federal agencies (the Securities and Exchange Commission and the Commodities Futures Trading Commission) that maintain divided jurisdiction over securities and commodities markets with state regulators offering supplemental oversight of securities firms, smaller investment advisers, and other areas of the securities business. Self-regulatory organizations, such as the Financial Industry Regulation Association (FINRA), contribute an additional layer of consumer protection in capital markets through quasigovernmental structures that combine industry participation and public oversight.

States are the most important regulators of insurance companies, with a complex system governing various lines of insurance (e.g., life and health insurance versus property and casualty) and insurance intermediaries (agents as opposed to underwriters or reinsurers). The federal government provides supervision of some important insurance products, most notably employerprovided health insurance, pensions and retirement savings plans. Federal and state governments also directly provide many forms of social insurance, including Social Security, Medicare and Medicaid, unemployment insurance, workers compensation, and flood insurance.

Some financial statutes are cross-cutting. For example, the privacy provisions of the Gramm-Leach-Bliley Act apply to all sectors of the financial services industry as well as to financial information retained by firms that do not engage in traditional financial activities. 
Enforcement, however, is delegated to sectoral regulators for regulated firms and the Federal Trade Commission for unregulated firms.

Other consumer financial statutes deal with specific financial functions. The Truth-inLending Act and the Equal Credit Opportunity Act, for example, apply to most forms of consumer credit. Some statutes apply more narrowly: the Real Estate Settlement Procedures Act, the Home Mortgage Disclosure Act, the Home Owners Protection Act of 1998, and the Secure and Fair Enforcement for Mortgage Licensing Act relate only to mortgages. Other statues address different features of consumer finance, including the Electronic Funds Transfer Act, the Fair Credit Reporting Act, the Credit Repair Organization Act, the Fair Debt Collection Practices Act, and the Truth in Savings Act.

Jurisdictional authority over these statutory requirements is complex and inconsistent. In many areas of consumer finance, especially areas involving consumer credit and payments systems, the Federal Reserve Board has had the authority to establish implementing regulations but enforcement is left to other agencies with direct oversight of regulated firms. In other cases, notably those tied to residential mortgages, the Department of Housing and Urban Development has had some rule-making authority. In still other areas, such as the oversight of credit repair organizations-that is, firms that purport to assist consumers in improving their credit scores-the Federal Trade Commission plays a leading role. The new Bureau of Consumer Financial Protection will centralize oversight of many of these consumer finance statutes (Department of Treasury 2009), although supervision will, in some cases, remain delegated to traditional frontline supervisory agencies in versions of the legislation pending in Congress. The Bureau's primary jurisdiction is largely limited to banking products - the provisions of credit, the collection of savings, and payment services - and does not extend to insurance, securities or employer-based fringe benefits, including retirement savings.

At the state level, various consumer financial protection laws prohibit unfair and deceptive practices; additional protections against unscrupulous business practices derive from common law doctrines in contract and tort law. In addition, the states maintain a variety of licensing and oversight arrangements for non-traditional financial intermediaries, such as mortgage brokers, real estate agents, payday lenders, pawnshops, check-cashing operations, and other specialized providers of financial services. Sometimes these entities are indirectly overseen by other regulators; for example, alternative financial service providers typically need to work with regulated banking partners.

The relationship between state-based consumer financial protection systems and federal law is at times controversial, especially where state authorities have attempted to apply local standards to federally chartered commercial banks or thrifts (Schiltz, 2004). The Dodd-Frank Wall Street Reform and Consumer Protection Act includes provisions that clarify the relationship between state and federal consumer finance regulation and expand the authority of state officials to police some aspects of the activities federally-chartered firms.

State and federal bankruptcy and tax laws also affect the structure of consumer financial markets. The bankruptcy code defines the conditions under which consumers can be discharged of financial obligations. Of particular note, some types of debt (e.g. mortgages secured by a 
primary residence and student loans) are more difficult to restructure in bankruptcy than others, and conversely, certain assets (e.g. employer sponsored savings plan balances and IRAs) are protected from creditor claims in bankruptcy (White, 2009; Jacoby, 2010). Similarly, the tax code favors certain types of assets, expenditures and debt. Mortgage interest is generally deductible from federal taxable income; most expenditures on employer-provided fringe benefits (notably health insurance, pensions, and retirement savings accounts) are not included in taxable income; and certain types of savings and capital accumulation receive tax preferences (Bittker and Lokken, 1999).

Finally, the financing programs of government sponsored enterprises (GSEs) such as Fannie Mae and Freddie Mac have profoundly impacted the evolution of consumer credit over the past half century. This is most evident in mortgage markets, but these innovations in mortgage finance have facilitated comparable mechanisms of private financing for other types of consumer credit (at least until market contractions following the recent financial crisis).

\section{B. The Mechanisms of Regulatory Intervention}

To address the market failures and distributional concerns outlined above in Part III, governmental authorities employ a vast array of regulatory tools. In this section, we follow Jackson (1999) and consider these various regulatory options, organized loosely from less to more interventionist, and concluding with several strategies that rely more on private actions than public oversight.

These interventions do not easily or precisely map onto the economic justifications for consumer financial regulation outlined earlier. Neither legislators nor regulatory agencies routinely justify their actions in purely economic terms. Political considerations and the views of key constituencies often play a major role in shaping the choice of regulatory tools. Government officials are sometimes subject to regulatory capture and fail to pursue policies that actually advance the public interest, whether defined in economic or other terms (Stigler, 1971).

Still, developing a catalog of regulatory options is instructive. Doing so may facilitate the formulation of preliminary hypotheses as to which approaches or combination of approaches would most suitably address the principal market failures associated with consumer financial markets. And one may also begin to develop criteria by which government authorities might ascertain which kinds of consumer financial transactions warrant the costs associated with more heavy-handed forms of intervention. ${ }^{12}$

Consumer Education and Financial Literacy Programs. Some of the simplest forms of government intervention in consumer financial markets are efforts to improve the financial literacy of consumers, either through curricular innovations in primary and secondary school education or through more general educational efforts (Hillman, 2009). A number of

\footnotetext{
${ }^{12}$ A partial list of considerations might include: size of potential injury (e.g., inappropriate mortgage vs. problematic gift card); lack of consumer sophistication (education, experience with products, etc.); limited capacity of consumers to protect self; salience of market forces; availability, efficacy, and cost of disinterested advice; product complexity (e.g. pricing, terms); and existence of cognitive biases or limitations (see Jackson, 2007).
} 
government programs are intended to promote such educational efforts, although the evidence of their efficacy is mixed at best.

Anti-Fraud Rules. Another traditional method of consumer protection is through antifraud rules which create a cause of action against parties that engage in intentionally deceptive selling practices. One innovation of the New Deal era federal securities laws was to expand the scope of anti-fraud rules for securities transactions to materially misleading omissions as well as misleading affirmative statements and to offer a host of procedural advantages to aggrieved purchasers or sellers of securities. Loosely analogous remedies are available under ERISA for deceptions arising out of employer benefits plans, but such liability rules are less common for banking and insurance transactions.

Disclosure Requirements. Perhaps the most straightforward response to information asymmetries is through disclosure requirements. Such requirements differ on a variety of dimensions. Some consist of affirmative obligations to disclose specific information about a product or provider. The SEC's disclosure rules for corporate issuers, for example, specify in considerable detail the kinds of information corporate issuers must include in their SEC filings and provide to investors under certain circumstances. Often the content of disclosures will be structured in highly prescriptive ways so as to facilitate consumer comparison across products. Examples include the annual percentage interest rate disclosures under the Truth in Lending Act for consumer credit and the annual, three-year, and five-year investment performance disclosure requirements for mutual funds. In some contexts, disclosures must be tailored to individual transactions, as is the case with settlement costs for home mortgages under the Real Estate Settlement Procedures Act. Finally, in contexts where it is difficult for customers to judge the significance of disclosures regarding individual transactions-for example, in securities transactions when the concern is whether a broker has achieved adequate price improvementdisclosures are required on an aggregate basis reflecting a large number of transactions over an extended period of time (Jackson 2008).

Fiduciary Duties. Another important category of legal protections in consumer finance are fiduciary duties. Typically imposed in situations where firms or individuals have discretionary control over the financial decisions of their customers, fiduciary duties impose legal obligations on fiduciaries to safeguard their clients' interests. In consumer finance, fiduciary duties are commonly imposed where a firm is giving financial advice or is engaged in the retail distribution of financial products. ${ }^{13}$ Similarly, ERISA imposes a wide range of fiduciary duties on the parties involved in the provision of employee benefit plans.

In the words of Justice Felix Frankfurter, "to say that a man is a fiduciary only begins the analysis." ${ }^{4}$ The scope and content of fiduciary duties can vary considerably across context

\footnotetext{
${ }^{13}$ One source of confusion among both consumers and industry experts is the variation of fiduciary duties across different sectors of the financial services industry. While securities brokers are subject to an extensive system of fiduciary duties imposed under both the Securities Exchange Act of 1934 and the requirements of FINRA, much less onerous obligations are imposed on selling agents in the insurance industry and on mortgage brokers (Jackson and Burlingame, 2007).

${ }^{14}$ SEC v. Chenery Corp., 318 U.S. 80, 85-86 (1943).
} 
(Langbein,1995). In some fields, such as securities regulations, fiduciary duties are defined by elaborate regulatory guidelines with clear requirements for determining, for example, whether fiduciaries have complied with suitability requirements or satisfied duties to obtain best execution. There are also differences in whether fiduciary duties can be waived through adequate disclosure and knowing consent on the part of the party or whether the duties are non-waivable. In the former case, the fiduciary duty can become little more than an open-ended disclosure requirement where the disclosing party bears the burden of establishing that the counterparty knowingly ascents to the disclosed terms. In the latter case, the duty functions more as a mandatory term of business. An example of the second category would be the FINRA mark-up rules which prohibit securities firms from marking up the price of securities by too great an amount when selling securities to customers from the firm's own account.

Non-Binding Standards. Another category of regulatory intervention that has become increasingly popular in recent years are default rules, opt outs, opt ins, and safe harbor provisions, which steer firms towards organizing their affairs in a certain way, but without imposing an outright mandate. Default rules are common in contracts and impose terms that presumptively apply unless the parties clearly choose to agree to other terms. Under federal securities laws, the default rule is that customers aggrieved with their broker-dealers can seek redress in federal courts, but firms can and typically do contract out of that regime by including an arbitration clause in agreements executed before opening new accounts. With opt-out requirements, a provider can establish its own policies, but the consumer must be given the opportunity to opt-out of that policy. The Gramm-Leach-Bliley Act rules for financial privacy protection are a good example. (Swire, 2003) With opt-in requirements, providers can only offer a service if a customer affirmatively chooses to accept the service, as is the case with the Federal Reserve Board's new rules on overdraft protection for electronic transactions. With a safe harbor provision, a firm is typically insulated from potential liability under some open-ended fiduciary standard if the firm complies with specific rule-like terms. So, for example, 401(k) plan sponsors can insulate themselves from various forms of liability by offering participants a range of diversified investment choices accompanied by certain disclosures.

In certain contexts - most notably where many but not all consumers would benefit from a certain requirement regime-non-binding standards may be preferable to mandatory requirements, which have less flexibility and may inhibit mutually beneficial transactions. Policy analysts focusing on the cognitive limitations of consumers sometimes advocate nonbinding standards as an effective means of nudging consumers towards what are assumed to be better financial decisions while leaving latitude for those with strong preferences to make other choices (Thaler and Sunstein, 2008). In devising these standards, a key concern is the degree of "stickiness" in the standard, that is, the degree of difficulty that consumers face in choosing to work outside the transaction. Also of concern is the extent to which financial services firms can steer consumers away from non-binding standards when it would be profitable to do so (Barr, et al., 2008).

Mandatory Requirements. A large number of consumer financial regulations take the form of mandatory requirements imposed on service providers and products. In many areas, there are licensing or chartering requirements before firms or individuals can engage in regulated activities. These are meant to ensure that providers have the requisite knowledge and 
experience and, in some cases, to prevent individuals with records of fraudulent past behavior from positions of responsibility or trust. Another set of mandatory requirements dictate the permissible structure of the balance sheet and business activities of financial intermediaries and their affiliates. These portfolio shaping rules, which include capital requirements, restrictions on investments, and regulation of the form of firm liabilities, are intended to reduce the riskiness of financial intermediaries and ensure their capacity to honor their commitments when they come due. $^{15}$ In certain sectors, financial intermediaries are also required to obtain third-party guarantees of their obligations. For example, most regulated depository institutions are required to participate in government-sponsored deposit insurance programs, and other financial service providers are often required to arrange private bonding arrangements before starting business. ${ }^{16}$

In some areas, mandatory requirements limit the form of financial products. For example, commercial banks are generally prohibited from offering secured deposits, lest one class of depositors obtain a priority in liquidation procedures. Similarly, the investment terms of mutual funds must include daily repricing and redemption of shares based on current market values of the underlying mutual fund portfolio. Consumer insurance products are extensively regulated with numerous restrictions on the form of permissible contracts.

Another category of mandates prevalent in consumer finance are anti-conflict rules which are designed to prevent the managers and controlling shareholders of financial intermediaries from applying the resources of the intermediary or customer funds for their own benefit. So, for example, commercial banks are limited in their ability to extend credit or engage in other transactions with affiliates. Comparable rules govern insurance firms and investment companies. The federal securities laws include similarly spirited requirements designed to prevent brokerdealers from misusing customer funds and securities. Some anti-conflict interventions take the form of restrictions on information flows-so-called "Chinese Walls"-designed to prevent employees dealing with customers from being pressured by other employees in ways that might be detrimental to the customers' interests. A good example are the settlements that arose out of the analysts' scandals of the late 1990s which imposed a series of structural barriers designed to prevent the investment banking side of securities firms from influencing the recommendations of affiliated analysts (Agarwal and Chen, 2008).

The existence of such extensive and often costly mandatory requirements for consumer financial products creates considerable incentives for parties to restructure their interactions so as to fall outside of regulatory requirements. In some areas, the law includes important explicit exemptions from regulatory requirements. For example, the Securities Act of 1933 includes the "private placement" exemption that relaxes the disclosure standards and liability for securities sold to sophisticated and wealthy investors. Similarly, the Investment Company Act of 1940 offers comparable exemptions that allow hedge funds and other alternative investment products to escape the onerous requirements imposed on mutual funds and other registered investment companies. Beyond these statutory exemptions, creative providers (and their attorneys) routinely

\footnotetext{
${ }^{15}$ Portfolio shaping rules are also important to prevent systemic risks from the failure of financial institutions.

${ }^{16}$ Organizational structure is also sometimes used as a regulatory instrument as when financial institutions are encouraged or required to organize in mutual form rather than the more familiar corporate structure with shareholders serving as residual claimants.
} 
seek to characterize their products as "mere" contracts so as to escape mandatory requirements and operate under the more liberal common law rules of "caveat emptor."

Price Controls and Rate Regulation. Price controls sometimes figure into consumer financial regulation. Usury rules, which restrict interest rates, are perhaps the most familiar example of this approach. While legal developments permitting depository institutions to export interest rates from the state of their choice has greatly weakened the efficacy of usury laws, for many consumer financial transactions, including payday lending, local usury rules are still relevant. Price controls in the form of rate regulation are sometimes used in the insurance industry, and all states prohibit the use of certain risk classifications (often including gender and sometimes geography) to set prices. The federal government recently added restraints on the use of genetic information to set insurance prices. Recently enacted federal health care reform imposes new restrictions on the ability of health insurers to discriminate among customers due to pre-existing medical conditions. Even in the securities field, there are restrictions on the pricing of certain consumer financial services, including distribution costs charged to mutual fund shareholders. Finally, anti-discrimination laws prohibit discrimination based on race and other suspect categories in the extension and pricing of credit.

Mechanisms of Enforcement. Enforcement is an important component of consumer financial regulation and consists of a variety of overlapping elements, including report requirements (both public and confidential); mandated internal controls (increasingly assigned to a chief compliance officer reporting to the highest levels of management); periodic examinations, including (in some sectors) examinations focused primarily on consumer protection issues; public enforcement actions ranging from informal to administrative to civil and then potentially criminal; and in some areas of consumer finance, most notably securities and employee benefit plans, robust private rights of action.

Third Party Validation. The public regulation of consumer finance is sometimes supplemented through systems of third party validation. One familiar example of this strategy is the common requirement that independent auditors review the financial statements of regulated intermediaries on an annual basis. But financial regulations also have increasingly relied on outside credit rating agencies as external (and, as it turns out, not particularly reliable) arbiters of permissible investments for regulated firms. In a different vein, the Investment Company Act of 1940 makes extensive use of independent directors to safeguard the interests of mutual fund shareholders, especially with respect to transactions when the interests of shareholders and investment company managers may be in conflict.

Supplemental Private Policing. Finally, our system of consumer financial regulation also often depends, and in some cases facilitates, the use of private policing. In the mutual fund industry, private vendors such as Lipper and Morningstar play an important role in digesting a massive amount of publicly available information about mutual funds and synthesizing that information for customers. Another area in which private order plays an important role is the sharing amongst financial firms of information about consumer defaults and credit performance. This collection of information permits the development of individual credit scores, which allows firms to determine credit risks and develop more accurate prices for loans and other credit 
transactions. ${ }^{17}$ Finally, in a variety of areas, industry groups promulgate standards of best practices, against which industry participants can assess their own practices. While these standards do not typically have formal legal standing, they often influence regulatory developments in the future and can form a sort of soft law around which many industry participants organize their operations in the short term.

Overlapping Strategies in Practice: One of the challenges of empirical studies into the efficacy of the different components of consumer financial regulation is that the components are rarely implemented in isolation. Rather, in most important areas of consumer finance, multiple forms of regulatory intervention are employed. The regulation of mutual funds, described below in our fourth case study, offers a good example. The mutual fund industry is often cited as a sector of the financial services industry that has benefited from successful and effective regulation, and the growth of the sector over the past several decades is consistent with that claim. But even accepting the assumption that effective regulation played an important role in the industry's success, it is difficult to ascertain whether some particular element of the mutual fund regulation made the critical contribution or whether the full smorgasbord of mutual fund oversight was necessary for the sector's success.

\section{Case Studies of Consumer Financial Markets and Their Regulation}

To illustrate how the themes discussed above apply to specific consumer financial markets we turn now to three case studies. In each, we discuss the market failures that are most relevant, the evolution of government regulation and its impact of firms and consumers, and the scope for further regulation to remedy existing problems. The case studies are (1) financing consumption in retirement, (2) residential mortgages, (3) payday lending; and (4) mutual funds

\section{Cast Study 1: Financing Consumption in Retirement}

Financing consumption in retirement illustrates many of the conditions under which retail financial markets may fail. The process of accumulating wealth for retirement when young and transforming that wealth into consumption when older involves long-term financial commitments that are large and consequential for most households. Moreover, many aspects of this particular problem allow for little direct or social learning-most of us only get to experience retirement once, and common shocks limit the extent of social learning.

In the U.S., the three largest financial resources of the elderly are home equity, social security benefits, and the value of employer-provided pension or retirement savings account balances. To this list we might also add a fourth significant financial resource - the implied value of the health insurance provided either by the government through Medicare or through former employers. This enumeration highlights one interesting aspect of the financing of retirement

\footnotetext{
17 This particular area of innovation has led to additional consumer financial regulation to protect consumers from errors in the creation of credit scores and abuses from firms that purport to have the capacity to improve an individual's credit score.
} 
consumption: In addition to the role played by financial institutions, employers and the government are also significant actors.

Government provision of retirement income is widespread (all major developed countries have some sort of social security system) and usually ascribed to various market failures such as under-saving (as a result of present-biased preferences) and adverse selection in the markets for retirement annuities and health insurance as well as to distributional concerns for the poor elderly. In the U.S., employer involvement in financing retirement consumption is largely motivated by the tax code which excludes from taxable income both employee and employer contributions to employer-sponsored pension and retirement savings plans. But employers are also in a unique position to help solve some of the problems that might otherwise lead to market failure, which may provide a motivation for subsidizing employer involvement in this market through the tax code. For example, employers may reduce search costs for employees by vetting financial providers, they may mitigate adverse selection by pooling individuals into employee groups, and they may alleviate problems that arise due to limited cognition or lack of financial literacy by acting as an agent on behalf of their employees. Employers may also negotiate better terms with financial providers than employees could obtain individually.

Beyond its direct role in providing retirement income through social security, government also regulates both financial service providers and employer provision of pensions and retirement savings plans. The evolution of government regulation over the past four decades, the relationship between regulation, financial service providers, employers and consumers, and the resulting changes in the market for financing retirement consumption illustrate the potential for government regulation to reshape markets in dramatic ways, sometimes intended and at other times not.

For several decades, the predominant form of employer-provided retirement income was the traditional defined benefit pension plan. In 1975, participants in employer sponsored defined benefit pension plans outnumbered participants in defined contribution plans by 2.4 to 1 (Department of Labor 2007). This situation began to change in the 1980s, precipitated by a series of new laws and regulations. The first, the Employee Retirement Income and Security Act of 1974 (or ERISA), was intended to protect current and former employees and their beneficiaries from employer abuses such as the underfunding of promised pension benefits or onerous vesting requirements. ERISA was followed in 1978 by the addition of section 401(k) to the Internal Revenue Code. A subsequent clarification in 1981 allowed employers to exclude employer and employee 401(k) contributions from taxable income.

None of these regulatory changes was passed with the intent to transform the pension landscape. The 401(k) plan was originally envisioned as a savings vehicle to supplement, not supplant, traditional defined benefit pension plans. But given the higher costs and regulatory restrictions imposed on defined benefit plans following ERISA, the 401(k) plan quickly became an attractive substitute for employers. By 2007, defined contribution participants outnumbered defined benefit participants by 3.4 to 1 , a striking and completely unanticipated reversal from three decades earlier (Department of Labor, 2007). 
In a defined benefit plan, employees have few choices to make: the employer determines the benefits to be paid in retirement and makes the contribution and investment choices necessary to make good on the promised benefits. In a traditional 401(k)-style defined contribution plan, employees choose how much to save and how to invest their contributions. The actual savings outcomes in these plans illustrate many of the problems discussed above that may give rise to market inefficiencies. Plan participation, contribution rates, and asset allocation outcomes are all heavily influenced by employer defaults, even when the costs of opting out are small (Madrian and Shea, 2001; Choi, Laibson, Madrian and Metrick, 2004; Thaler and Benartzi, 2004; Choi, Laibson and Madrian, 2005; Carroll, Choi, Laibson, Madrian and Metrick, 2009); participants chase past returns in both their asset allocation and contribution rate choices (Benartzi, 2001; Choi, Laibson, Madrian and Metrick, 2004 and 2009); they fail to rebalance (Ameriks and Zeldes, 2004; Mitchell, Mottola, Utkus and Yamaguchi, 2006); and their asset allocation choices are sensitive to the structure of the investment menu (Benartzi and Thaler, 2001; Brown, Liang and Weisbenner, 2007). These outcomes are suggestive of both presentbiased preferences and cognitive limitations on the part of defined contribution plan participants.

Concern that savings outcomes in defined contribution plans were suboptimal motivated several key provisions in the Pension Protection Act of 2006 (PPA), the biggest regulatory reform of pensions and retirement savings plans since ERISA. The PPA includes inducements (safe harbors) for employers to structure their savings plans to incorporate automatic enrollment, automatic contribution escalation, and a diversified default asset allocation. These plan features help circumvent the tendency for employees with present-biased preferences to delay participating in an employer-sponsored savings plan or to choose a contribution rate that may be too low. Passage of the PPA is credited with driving significant increases in the fraction of plans that have such features. For example, Fidelity Investments (2009), the largest 401(k) plan administrator in the U.S., reported a 70\% increase in the fraction of its sponsors offering automatic enrollment between 2007 and 2009. By 2009, nearly half of its participants were in plans with automatic enrollment. Fidelity also reports that nearly all (96\%) of its automatic enrollment plans now use target date funds as their default investment option. ${ }^{18}$ This is a striking change from earlier years, when the default investment funds chosen by employers were predominantly money market or stable value funds. Park (2009) estimates that nearly $7 \%$ of 401(k) assets were invested in target date funds at the end of 2008. This fraction is likely to increase substantially in the coming years as more 401(k) plans adopt automatic enrollment and as the fraction of employees who have been automatically enrolled into such funds increases. If so, this would mark a significant change in the nature of 401(k) investments.

Whether these provisions of the Pension Protection Act improve long-run retirement income security remains to be seen. There is the possibility that these measures may increase savings within defined contribution savings plan but only by crowding-out savings elsewhere or by increasing consumer debt. But recent evidence on savings-related crowd-out suggests that the effects are largely confined to higher income households (Engelhardt and Kumar, forthcoming). In any case, there is certainly scope for further regulation within the current defined contribution

\footnotetext{
18 Target date funds include a mix of domestic and international equities, bonds, and short-term securities. The allocation between these asset classes changes over time as investors approach retirement
} 
dominated system. ${ }^{19}$ First, regulation can promote access: employer sponsored savings plans are limited to those whose employers offer them, and coverage is by no means universal. Pending legislation would establish automatic IRAs, a step in the direction of expanding access to workplace-based savings plans (Iwry and John, 2009).

Second there is a case for regulation to promote annuitization of retirement wealth. Retirees face a problem of how to liquidate their holdings to fund living expenses. Few individuals annuitize any part of their defined contribution account balances at retirement even though most economic models suggest that they should, a fact commonly referred to as the "annuity puzzle". ${ }^{20}$ Such regulation could take the form of tax incentives for annuitization, mandated full or partial annuitization (as is the case in the U.K.), or inducements for plan sponsors and financial service providers to innovate in the creation of annuity-like products that could be incorporated into defined contribution savings plans.

Third, the investment options in employer-sponsored savings plans are not necessarily appropriate for the task they are designed to facilitate. Employer stock is a commonly available and popular investment choice in the savings plans of publicly traded firms, even though its risk properties (it is undiversified and its returns are correlated with the returns on labor income) make it a poor investment choice. Conversely, investment options that do make sense, notably longer-term illiquid investments that carry a liquidity premium, are not part of the mutual funds that populate plan investment menus because they are not amenable to the daily valuations of such funds. Regulation to align plan investment options with investor needs is warranted.

\section{Cast Study 2: Residential Mortgages}

The residential mortgage market is another illustration of many of the themes of this paper. Just as in the case of retirement saving, government policy has had an enormous influence on the U.S. system of housing finance. For the last 75 years, the dominant mortgage form in the U.S. has been the long-term, nominal, amortizing fixed rate mortgage (FRM). This type of mortgage, unusual in other countries, has been fostered by implicit public subsidies through the government sponsored entities (GSEs), most notably Fannie Mae and Freddie Mac.

\section{Negative externalities from foreclosures}

One rationale for government policy in this area is a public interest in reducing the incidence of foreclosures. There is evidence that foreclosures not only damage foreclosed properties, but also reduce the prices of neighboring properties (Campbell, Giglio, and Pathak, 2009). The negative effect on the neighborhood is an externality that will not be taken into account by private lenders even if, as suggested by Foote, Gerardi, Goette, and Willen (2009), their foreclosure decisions are privately optimal.

\footnotetext{
${ }^{19}$ Some are less sanguine about the potential for adequately reforming defined contribution savings plans and have called instead for completely scrapping the current system in favor of mandatory savings schemes (Ghilarducci, 2008) or a return to defined benefit pension plans.

20 The annuity puzzle is not restricted to defined contribution participants — an increasing fraction of defined benefit pension beneficiaries are opting to take a lump-sum at the time of retirement rather than the tradition annuity.
} 
The U.S. experience during the Great Depression suggests the importance of this point. In the late 1920's the dominant mortgage form was a short-term balloon loan that required frequent refinancing. When low house prices and reduced bank lending capacity in the early 1930's prevented many homeowners from obtaining sufficient new mortgage credit to pay off their maturing loans, the result was a wave of foreclosures that exacerbated the Depression. Many observers are concerned that a similar process is unfolding today.

Foreclosures can be reduced ex ante, by encouraging mortgage forms such as FRMs that pay down principal over time and thus rely less heavily on foreclosure to protect the interests of the lender; and ex post, by regulations that encourage or require mortgage modification as an alternative to foreclosure. The Obama Administration has subsidized mortgage modification with limited results. A more radical alternative, discussed by White (2009), would be to alter the bankruptcy code to allow bankruptcy judges to modify mortgage terms.

\section{Consumer cognitive limitations}

Consumer cognitive limitations provide a second rationale for mortgage regulation. For many households, mortgages are both the largest and most important financial arrangements that they make and a serious challenge to their cognitive abilities. A great variety of mortgages are available, some of which are complex and pose risks that are difficult even for financial professionals to thoroughly understand. Mortgage costs appear in a number of forms, not all of which are straightforward to measure. Households take out mortgages relatively infrequently, and often negotiate them at the same time that they are moving homes. Under these circumstances it is unlikely that all households make perfectly optimal decisions.

\section{The choice of mortgage form}

One important aspect of mortgage choice is the decision between a FRM and an adjustable rate mortgage (ARM). The FRM has some important advantages. The predictability of nominal payments simplifies the household's financial planning problem provided that inflation is relatively stable. The mortgage has an option to refinance, protecting the household against unexpected declines in inflation during the life of the mortgage that would otherwise increase the real debt burden.

However the FRM is not a perfect financial instrument. It has at least three major problems. First, the real value of the mortgage is extremely sensitive to inflation. Given a refinancing option, the mortgage amounts to a massive one-way bet on inflation, in which homeowners benefit if inflation erodes the real value of their debt, but can refinance to a lower nominal interest rate if inflation falls. The inflation exposure of nominal FRM lenders creates systemic risk to financial institutions, a fact that became apparent in the U.S. during the savings and loan crisis of the 1970s and 1980s. Once lenders become aware of inflation risk, they compensate for it by charging high rates for long-term nominal FRMs. In countries with more volatile inflation histories than the United States, this has made these mortgages prohibitively expensive. 
Second, long-term nominal FRMs require homeowners to decide when they should refinance. Given the monetary and time costs of refinancing, this is not a trivial decision and, in fact, is an example of a sophisticated "real options" optimal investment problem. Campbell (2006) presents evidence that in the late 1990s and early 2000s, many households paid higher mortgage rates than they needed to, particularly less educated and less wealthy households.

Third, an environment of rising house prices and declining interest rates, of the sort that existed in the United States during the 1990s and early 2000s, presents an opportunity for refinancing homeowners to extract home equity by increasing their mortgage balances. To the extent that homeowners have present-biased preferences, this is a dangerous temptation that reduces saving (Khandani, Lo, and Merton, 2009).

There are of course alternatives to the long-term nominal FRM that mitigate these problems. The adjustable rate mortgage (ARM) amortizes the nominal principal of the mortgage loan in a similar fashion to the FRM, but charges an interest rate that adjusts to variations in market rates and therefore indirectly to variations in inflation. Over the lifetime of an ARM the real present value of mortgage payments is approximately invariant to inflation, there is never any reason to refinance to obtain a lower interest rate, and therefore refinancing does not tempt homeowners to extract home equity. Furthermore, an ARM normally has a lower interest rate than a FRM since lenders need not charge homeowners the cost of a one-sided bet on inflation. For these reasons Alan Greenspan (2004) famously argued that some U.S. homeowners would benefit by shifting from FRMs to ARMs.

However, the ARM has problems of its own. Although the present value of ARM mortgage payments is invariant to inflation, the cash flow consequences are material. An increase in inflation increases nominal payments today by more than the increase in the price level - that is, it increases required real payments - to compensate lenders for the erosion of the real value of their principal. This acceleration in the required repayment schedule causes serious problems for households that lack alternative means to borrow, a point emphasized by Campbell and Cocco (2003). More generally, the variation in required nominal interest payments complicates the household's financial planning problem and may be hard for some households to understand. $^{21}$

In the late 1990s and early 2000s, new forms of ARMs emerged that added to these problems. Because ARMs do not have fixed monthly payments, it is comparatively straightforward to alter their terms to require lower payments initially. It became common to offer a low initial "teaser rate", which was sometimes fixed for a number of years in "hybrid ARMs”, and during the initial period lenders sometimes waived required principal payments in "option ARMs". After the initial period, many of these mortgages charged penalty interest rates which made it highly desirable to refinance them if at all possible. These mortgages are similar to those that prevailed in the U.S. before the Great Depression in that they lead to defaults and

\footnotetext{
${ }^{21}$ Bucks and Pence (2008) present evidence that households with ARMs systematically underestimate the degree to which their mortgage interest rates can vary over time.
} 
require foreclosures if refinancing is not available. However, they are considerably more complex and therefore harder for households to evaluate and manage. ${ }^{22}$

Economists have suggested alternative mortgage forms that may be superior to any of those observed in the marketplace. For example, an automatically refinancing FRM with no home equity extraction would address two of the three problems with a conventional FRM. By automatically lowering required monthly payments when long-term nominal interest rates decline sufficiently, such a mortgage would eliminate discretion over refinancing and the temptation to deplete home equity at refinancing dates. An inflation-indexed FRM, whose payments would increase with the price level, would eliminate the remaining problem of inflation sensitivity. In a similar spirit, ARMs could be constructed with level nominal or real payments and a principal balance that adjusts to variation in short-term nominal interest rates. Finally, some economists have advocated mortgages with principal balances that automatically adjust to the regional level of house prices (Shiller, 2008).

If such contracts would be superior to existing mortgage forms, why do they not appear and indeed dominate the marketplace? One general response is that given the cognitive challenges facing households, there is only a weak presumption that financial innovation will offer genuinely advantageous products to households; it is just as likely that innovators will design superficially attractive products that cater to household behavioral biases. In support of this view, it is striking how different types of mortgages dominate in different developed countries, even though the underlying financial problems of households are similar in the United States and many parts of Europe. Some of this cross-country variation may be explicable by different inflation histories and government policies, but to the extent that the best solutions to household financial problems are similar everywhere, the diversity of mortgages across countries suggests that financial markets are not consistently providing these best solutions.

Gabaix and Laibson (2006) have suggested one mechanism that can inhibit useful financial innovation. If some households lack awareness of their own cognitive limitations, they may fail to anticipate their inability to refinance a conventional FRM optimally. Such households will pay higher mortgage rates than they need to, generating profits to mortgage lenders that in competitive equilibrium lower the interest rates on conventional FRMs. Sophisticated households, who do know how to refinance their mortgages, will find conventional FRMs to be attractively cheap because they benefit from a cross-subsidy from naïve households. Therefore sophisticated households will not wish to take out an automatically refinancing FRM, and financial entrepreneurs offering such a product will not be able to win customers either by advertising to sophisticated households or by educating naïve households to become sophisticated.

There are several ways in which consumer financial regulation can help improve the forms of mortgage contracts. Most obviously, disclosure requirements can facilitate risk

\footnotetext{
${ }^{22}$ Miles (2003) presents intriguing evidence that households in the UK, where ARMs with teaser rates are standard, failed to manage them properly in the early 2000s. He shows that almost $1 / 3$ of UK households were paying a higher rate than they could get by taking out a new ARM. Similarly, it has been claimed that many U.S. households took out complex subprime mortgages during the recent credit boom even though they would have qualified for cheaper prime mortgages.
} 
comparison across mortgage forms. In this regard it is key to offer households measures of risk as well as expected cost. Standard APR calculations are helpful for comparing mortgages with similar risks, but not for comparing FRMs with ARMs, or for comparing ARMs with different initial fixed-rate periods, interest rate caps, and other complex features.

An alternative approach is to promote standard mortgages. The case for doing this is that one or two standard mortgages may be reasonable choices for most households; if these mortgages are offered as a default option, many households will choose them and this may reduce the incidence of financial mistakes.

In the past, U.S. government sponsorship of the GSEs subsidized long-term nominal FRMs and helped them become de facto standard mortgages. The costs of this policy became apparent during the recent financial crisis when the government was forced to assume losses incurred by Fannie Mae and Freddie Mac. A more explicit regulatory policy favoring certain mortgages, for example by lowering capital requirements on banks holding them, or by requiring consumers to qualify for non-standard mortgages, may be a preferable alternative. ${ }^{23}$

Given the well documented problems with existing mortgage contracts, it is important not to choke off the development of new and potentially superior mortgages. If certain mortgages are given favorable treatment as standard mortgages, new products should be considered for this treatment if it can be shown that they meet consumer needs and are comprehensible to households considering them. An important function of the new Bureau of Consumer Financial Protection will be to evaluate proposed new products through economic analysis and field research.

\section{Cost comparison}

An equally important aspect of mortgage choice is cost comparison. Mortgage costs take different forms, some being included in the interest rate and others charged up front. A mix of one-time and recurring costs is particularly hard to evaluate because their relative importance depends on the length of time that the mortgage is held. Standard APR calculations assume that mortgages are held to maturity and can be seriously misleading for mortgages that are typically refinanced after a few years.

Consumer financial regulation can simplify the task of cost comparison in several ways. The existence of standard mortgages is helpful in itself, because households can concentrate on standard mortgage terms rather than considering a vast array of special features. ${ }^{24}$

Disclosure policy is obviously relevant, and both the Federal Reserve Board and the Department of Housing and Urban Development have recently augmented disclosure

\footnotetext{
${ }^{23}$ The Federal Reserve Board's 2008 amendments to regulations implementing the Home Ownership and Equity Protection Act impose new and stringent underwriting standards for "higher priced mortgage loans" associated with the subprime crisis.

${ }^{24}$ Woodward (2003) presents evidence that households pay lower mortgage fees when all fees are rolled into the interest rate, simplifying the task of cost comparison.
} 
requirements surrounding mortgage originations. There is however an important issue of making disclosures comprehensible to consumers and available in a timely manner, during the period of comparison shopping rather than at the time of closing on a house purchase. Thaler and Sunstein (2008, Chapter 8) have proposed that mortgage terms be made available electronically in standardized form to permit the development of online sites for comparison shopping.

An alternative approach is to regulate the mortgage origination process. In 2008, Congress passed the Safe Mortgage Licensing Act with the goal of establishing minimum state standards for licensing mortgage originators. A more drastic approach would be to establish a fiduciary duty for mortgage brokers.

\section{Cast Study 3: Payday Lending}

To illustrate how the themes discussed above in Sections III and IV apply to specific consumer financial markets we turn now to a case study involving payday loans (PDLs): relatively small, short-term, generally unsecured loans that are often sold to less well-to-do consumers, many of them at a physical point of sale. This form of lending has grown rapidly in recent years, and the industry now estimates loan volume at roughly $\$ 40$ billion per year. ${ }^{25}$

\section{Background}

Most PDLs follow a relatively standard lending process and take a relatively standard form. Consumers visit a storefront location, request a loan, have their employment verified, and if approved, walk out minutes later with the loan proceeds. The average PDL is fairly small-$80 \%$ of transactions are for less than $\$ 300$ (Stegman, 2007). The loan comes due on the borrower's next payday and is extinguished by either an explicit payment from the borrower, a pre-arranged ACH withdrawal from the borrowers' bank account, or by cashing a post-dated check. The time until the next payday, and hence loan maturity, can range from a few days to nearly a month, but the norm is two weeks. Instead of a finance charge that varies with balance and duration of the loan, the fee is either fixed or related simply to the loan amount, typically $\$ 15$ to $\$ 30$ per $\$ 100$ borrowed (Stegman, 2007).

In some states, borrowers can repay the loan (plus fee) by rolling it over to a new, higher balance loan. Some states limit same store roll-overs to no more than four or five per year; in others, they are prohibited entirely. Even in such states, nothing prevents a borrower from getting another loan elsewhere. According to Elliehausen (2009), 40\% of payday loan consumers used more than one payday lender within a 12 month period, and of those, over 35\% used a PDL from one lender to pay off another. ${ }^{26}$

\footnotetext{
${ }^{25}$ Community Financial Services Association of America (CFSA) is the national payday lending industry association: http://www.cfsa.net. Caskey $(1994,2001,2002)$ provided some of the earliest research documenting this form of what he called “fringe banking." For a more recent overview of PDL, see Stegman (2007).

${ }^{26}$ Many other studies also document sizeable repeat PDL usage. Stegman and Farris (2003) report that the average PDL user took out seven loans in 2000, and the Center for Responsible Lending reports that $90 \%$ of loans were made to borrowers with five or more transactions per year (Parrish, 2008). Lawrence and Elliehausen (2008) find that $20 \%$ of PDL customers rolled over more than eight loans in a twelve month period. Flannery and Samolyk (2005) find that $46 \%$ of store PDL transactions were rollovers, accounting for $34-40 \%$ of total loan volume.
} 
By virtue of the product itself, PDL customers must have a checking account and be employed. Lawrence and Elliehausen (2008) find that PDL customers tend to have a moderate level of education and are disproportionately young (under age 45) and have children. Most are from lower and middle-income households with limited liquid assets-fewer than half report any savings (Elliehausen, 2009). ${ }^{27}$ Generally, they are in life stages where demand for credit is high, and although 92\% rely on other types of credit, many have been denied credit in the past 12 months, have credit cards at the limit, have concerns about their ability to access credit, and are less likely to have home equity to tap (Elliehausen and Lawrence, 2001; Lawrence and Elliehausen 2008).

Payday lending grew out of the check cashing industry of the 1990s and the leading industry association reports almost 24,000 outlets nationally. ${ }^{28}$ The industry is fairly dispersed with only a few large corporations holding any substantial share of the market-most payday lenders are small storefront operations. ${ }^{29}$ The few studies on payday lending profitability rely on self-disclosed figures, and hence may not be representative or objective, but suggest that the business is not as profitable as critics charge. Flannery and Samolyk (2005), for example, analyzed data for 300 stores in two chains. They conclude: "fixed operating costs and loan loss rates do justify a large part of the high APRs charged on payday advance loans" and that loan volume, rather than repeat borrowing per se, is a primary determinant of profitability. Similar conclusions are reached by Tufano and Ryan (2009) who conduct a case study of a single chain, and by Huckstep (2007) and Skiba and Tobacman (2007) who examine the financial statements of publicly traded payday lenders.

\section{Applying the Regulatory Justifications to Payday Loans.}

Earlier in Section III we outlined several rationales for regulation of consumer financial markets. Here we consider their application to payday loans.

Traditional market failures seem an unlikely basis for regulation of PDLs. There is little evidence of market power. ${ }^{30}$ The apparent absence of abnormal profits may reflect competition, the small scale of most operations, the requirements for both local real estate and personnel, and loan losses. In some low income communities, the number of PDL outlets far exceeds the

\footnotetext{
${ }^{27}$ The most-reported household income levels of PDL customers are: $\$ 25,000$ to $\$ 39,999$ (27.6\%), $\$ 15,000$ to $\$ 24,999$ (17.6\%) and \$50,000 to \$74,999 (16.7\%). Nearly all PDL borrowers have a high school diploma (91.2\%) and many have some college (35.1\%) (Elliehausen 2009). See also Stegman and Faris (2003). One can also characterize borrowers with regard to their larger pattern of financial service experiences. Lusardi and Tufano (2009) find that payday borrowers are more likely than others to engage in related high cost financial transactions. ${ }^{28}$ See http://www.cfsa.net/about_cfsa.html.

${ }^{29}$ Stegman (2007) estimates that six large companies control about one-fifth of all PDL activity.

${ }^{30}$ However, as Mann and Hawkins (2007) argue, the most convenient locations for customers are more expensive, which may privilege established firms, put a "natural limit on the density with which profitable locations can be established" and "hinder the effectiveness of price competition.” DeYoung and Phillips (2009) conclude that loan pricing reflects strategic considerations, with fees rising to legislated ceilings and with large multi-store firms charging higher prices than independent single store operators.
} 
number of banks and even fast food restaurants. ${ }^{31}$ Given the prevalence of PDLs in selected neighborhoods and the relatively standard terms in the industry, it is reasonable to suppose that consumers have low search costs. Similarly, there don't appear to be asymmetries of information or public good aspects of payday lending that would justify additional information regulation, although standardized APR disclosures required of payday lenders under the federal Truth-inLending Act do provide a useful baseline of information, which might not be available in an entirely unregulated market.

There is mixed evidence on whether PDLs generate externalities. Some evidence suggests that PDLs lead to financial hardship, which could give rise to greater need for public or private redistribution ex post. Other evidence suggests that PDLs may give rise to positive externalities: Morse (2009) finds that households facing natural disasters were less likely to experience foreclosures or larcenies when PDLs were more accessible. Wilson et al. (2010) replicate Morse's general result using a laboratory experiment with 318 undergraduate subjects who had to manage a household budget over 30 periods. They found that the addition of PDLs to a mix of credit products helped subjects absorb expenditure shocks. Comparative evidence from Oregon, which imposed a PDL interest rate cap, and the neighboring state of Washington, which did not, shows that restricting access to PDLs causes "deterioration in the overall financial condition" of households (Zinman, 2008). This evidence suggests that PDL may be better than its alternatives.

By contrast, other studies find that PDLs are associated with increased financial hardship, and thus perhaps negative community externalities. Melzer (2009), for example, exploits geographic and temporal variation in the availability of PDLs and finds that loan access leads to increased difficulty paying mortgage, rent and utility bills; a higher rate of moving out of one's home due to financial difficulties; and delayed medical care, dental care and prescription drug purchases. $^{32}$ There also is evidence that PDLs are associated with adverse outcomes for military borrowers, including declines in overall job performance and lower levels of retention (Carrell and Zinman, 2008). To discourage PDLs to military personnel, the 2007 National Defense Authorization Act caps the fees on payday loans to service members at a 36\% APR, a regulation that industry critics support for all payday lending (CRL Research Brief, 2009).

Behavioral considerations for PDL regulation include both cognitive limitations and present-biased preferences of borrowers. There is a limited amount of direct and indirect

\footnotetext{
${ }^{31}$ The geographer Graves (2003) reports that PDL and bank branches are inversely related, with loan stores growing in areas where banks are exiting: poorer communities with a larger fraction of minorities. Morse (2009) reports the number of PDLs per zip code in California in 2007 was twice as large as the number of McDonalds restaurants (1.9 vs. 0.95).

${ }^{32}$ Using a regression-discontinuity approach applied to borrower-level data from Texas, Skiba and Tobacman (2009) conclude that loan approval for first-time PDL applicants increases the likelihood of Chapter 13 bankruptcy filings by $2.5 \%$ through two channels: a selection effect-higher risk borrowers both seek PDLs and go bankrupt; and repeated borrowing. In contrast, Stoianovici and Maloney (2008) use state-level data and find no relationship between PDLs and bankruptcy filings. Morgan and Strain (2008) find that PDL restrictions increase credit problems such as the incidence of bounced checks. However, using finer data, Campbell, Martinez-Jerez and Tufano (2008) find fewer involuntary bank account closures due to overdrafts after Georgia banned payday lending, especially for individuals farther from state borders where PDL was available nearby.
} 
evidence that PDL users may have cognitive limitations. Lusardi and Tufano (2009) find that PDL borrowers and users of other forms of non-traditional credit have low levels of debt literacy (an understanding of interest compounding). As part of a field experiment, Bertrand and Morse (2009) asked PDL borrowers about the interest rate charged for their loans. About $40 \%$ claimed the APR was around 15\%, confusing the cash charge per hundred dollars and the APR (or they misunderstood the question). Some PDL borrowers take out loans even when they have access to lower cost credit in the form of unused credit card borrowing capacity (Agarwal, Skiba and Tobacmann, 2009) or savings and checking account balances (Carter, Skiba, Tobacmann, 2010). While there may be a logical reason for these choices (e.g., lower intra-family disclosure or avoidance of overdraft fees), to the extent that they demonstrate a failure to understand the relative costs of alternative forms of credit, the "diagnosis" might be one of cognitive failures. Finally, as noted earlier, there is substantial evidence of repeat or chronic borrowing. ${ }^{33}$ In states allowing rollovers, borrowers can quickly see their borrowing balloon out of control. This could reflect cognitive limitations of PDL borrowers; it could be indicative of present-biased preferences-individuals underweight the future costs of taking out a PDL today; or, it could simply reflect the fragile economic state of many PDL users. Collectively this evidence is consistent with a behavioral basis for regulation, even if the empirical evidence is still rather limited.

The distributional arguments for regulating PDLs are straightforward: the poor (or poor financial managers) pay more. As noted above, PDLs are used disproportionately by less well off individuals. Critics charge that PDLs are in fact targeted to (and thus used by) lower income consumers and racial minorities (Graves, 2003; Stegman and Faris, 2003). Critics further argue that PDL pricing is "predatory"-typical fees of \$15-\$20 per \$100 borrowed imply an APR from 390\% (if paid back at the two-week deadline) to over 1000\% (if repaid within one day). In some regulation, such as the Home Ownership and Equity Protection Act of 1994 (HOPEA), the mere existence of high APRs, defined in reference to prevailing rates, is the basis for regulation.

While detractors argue that PDLs result in the poor paying more, one must ask "more than what?" Defenders of PDLs point out that other sources of short-term credit, such as overdraft protection, returned check fees, and credit card late fees, have APRs ranging from $478 \%$ to $791 \%$, depending on the duration of the loan (Consumer Reports, 2005; Lehman, 2005). Furthermore, the costs of not having access to credit can be extraordinarily high. For example, if electricity or telephone service is shut off, the time and expense to restart service can far exceed a PDL fee. ${ }^{34}$ Similarly, a worker lacking the funds to repair a vehicle may be unable to get to work and may lose her job as a result.

The effects of payday lending on household welfare depend on the assumed alternative to PDL usage. If PDLs were not available, some households may find less convenient but perhaps

\footnotetext{
${ }^{33}$ A report by the Center for Responsible Lending (King et al., 2006) claims that repeat borrowers generate $90 \%$ of the revenue of the PDL industry. However, Veritec, LLC, a data provider for the industry, disputes these statistics in a report dated January 18, 2007 (see http://www.cfsa.net/veritec.html).

${ }^{34}$ The Community Financial Services Association of America (2006) commissioned a study to document the fees of PDL alternatives. Their findings are: late fees for utilities, $\$ 9.92$; utility reconnect fees, $\$ 36.24$; insufficient funds fees, \$28.34; and bank overdraft fees, \$23.18.
} 
less expensive financing, or may resist the temptation to engage in short-term spending. Other households, however, may use more expensive forms of short-term credit, or suffer severe consequences from lack of credit. Which counterfactual one believes will inform one's view of appropriate regulation; the existing empirical evidence provides mixed answers.

\section{Existing Regulation}

In response to the efforts of several national banks that were attempting to establish nationwide distribution networks through local payday lenders, federal banking authorities took a series of steps starting in 2000 to discourage federally-insured depository institutions from participating in payday lending (Smale, 2005). As a result, payday lending is largely conducted and regulated at the state level (Peterson, 2008). Georgia prohibits payday lending entirely and nine other states effectively prohibit it as a result of interest rate caps that make it unprofitable. ${ }^{35}$ Annual interest rate caps also exist in some states with payday lending, including Ohio (28\%), New Hampshire (36\%), Oregon (36\%), and Virginia (36\%). The Truth-in-Lending Act requires that the loan amount, finance charges, and APR must be clearly disclosed in any contract or agreement the borrower signs. Thirty states have more stringent disclosure laws, requiring payday lenders to clearly and prominently post APRs and fee schedules inside their stores. ${ }^{36}$ Many states limit the maximum loan amount, and some states, such as California, prohibit rollover loans. Thus, the range of regulatory practices extend from an outright or de facto ban (through low permissible APRs) on one extreme to disclosure requirements on the other, with a middle ground of restrictions on contract terms (e.g. repeat usage).

\section{Policy considerations}

The discussion above highlights the problems with crafting optimal regulation of payday lending. While distributional considerations and externalities may form the case for regulation, there is conflicting evidence about whether PDLs benefit or harm consumers. Likely they do both. Used "responsibly" as an alternative to even higher cost borrowing or the failure to pay certain bills, PDLs are likely beneficial-as the industry argues. But when used repeatedly, they can lead to ballooning debt and distress — as critics argue. Any regulation must address how the product is used by the borrower.

Regulation cannot deal with PDLs in isolation. Taking the functional perspective, PDLs are just one form of short-term credit. Regulation restricting one product can lead consumers to seek other, possibly even less attractive, sources of credit. That PDLs are used in conjunction with other short-term credit products reminds us that any regulation must assist consumers in making decisions that cut across various products. This "help" might come in the form of education or disclosures.

\footnotetext{
${ }^{35}$ These are: Connecticut, Maryland, Massachusetts, New Jersey, New York, North Carolina, Pennsylvania, Vermont and West Virginia. See regulations by state at the National Conference of State Legislatures, http://www.ncsl.org/IssuesResearch/BankingInsuranceFinancialServices/PaydayLendingStateStatutes/tabid/12473/ Default.aspx.

${ }^{36}$ Fox and Woodall (2006), however, report that three fourths of surveyed payday lenders failed to post the APRs as required by law, and $20 \%$ posted no cost information at all.
} 
If behavioral considerations are the basis for greater regulation, then we need to know more about what drives PDL choice before we can craft more effective (and appropriate) regulation. Well designed disclosure can in principle help consumers make better decisions, but existing research calls into question whether it will substantially change behavior. A recent randomized field experiment by Bertrand and Morse (2009) tested different types of PDL disclosures. They find that fee disclosure in dollar terms was more effective in reducing same store PDL demand than APR disclosures ${ }^{37}$ or messages about the likelihood of repeat borrowing or the importance of budget planning. However, the absolute reduction in subsequent borrowing was modest (5 to $6 \%$ depending on the specification), and the experiment could not assess whether reduced borrowing at the participating payday lender was offset by borrowing from other payday lenders. Overall, these results raise questions about the efficacy of disclosure rules. ${ }^{38}$

To the extent that the most problematic use of PDLs relates to repeat usage, the underlying failure could be either behavioral or structural (in that people are systematically living beyond their means). If the former, it might be possible to employ other behaviorallyinformed regulatory changes (Barr et al., 2008). For example, if PDL borrowing is an impulse item, then a short "cooling off" period might give people time to consider whether they really want a loan. In the market for tax refund anticipation loans, many consumers are willing to accept a wait of one or two days for payment rather than incur additional fees to access their impending tax refunds on the same day as they file (Cole et al., 2008). If the problem is structural in that people simply can't manage their money, barring rollovers-or PDLs altogether-won't address the basic issue that gives rise to the product.

It seems sensible that policymakers should test the likely impact of any proposed rule changes. The experiments cited above were mostly conducted by scholars, rather than by the policymakers charged with rule-making. Most academics, however, seek to publish papers, and do not have the time nor inclination to test micro-variations in rules. As a result, some form of research needs to be carried out by policymakers themselves.

While regulation may seek to protect consumers, it needs to be mindful of the economics of this business. It is difficult to make the case that most lenders are earning supernormal profits. However, pending House and Senate bills (H.R.1608 and S.500) would cap interest rates at a $36 \%$ APR, similar to the limit imposed on payday loans for military personnel in 2007. For a \$300 two-week loan, a 36\% APR rate cap would limit the lender's total revenue to \$4.15 $(300 * 0.36 / 26)$. According to Flannery and Samolyk (2005), average loan losses alone were $\$ 5.72$ per loan for the most mature stores, before accounting for the cost of wages, buildings, advertising or overhead. A 36\% APR ceiling would not create "affordable" PDLs, but could

\footnotetext{
${ }^{37}$ The conclusion that dollar-based versus APR disclosure is most informative echoes the results of Hasting and Tejeda-Ashton (2008) who find a similar result in their study of responses to fee disclosure for investment accounts in Mexico.

${ }^{38}$ Choi, Laibson and Madrian (2010) and Beshears, Choi, Laibson and Madrian (forthcoming) find that mutual fee disclosures are similarly ineffective.
} 
instead lead to the exit of existing vendors. More generally, rate caps could lead to new products or practices that skirt the rules, ${ }^{39}$ or push payday lending underground. On the other hand, rate caps and other PDL restrictions could spur legitimate innovation into products that are both better for consumers and profitable for firms.

Finally, the correlated use of PDLs and other short-term lending products and the growth of the PDL industry probably reflects desire by consumers for access to short-term credit. A different regulatory approach would be to encourage alternatives to PDLs. Before she assumed her role as Chairman of the FDIC, then-academic Sheila Bair (2005) reviewed PDL alternative models. Among her conclusions, she called for regulatory encouragement for low-cost shortterm loans. As FDIC Chair, she launched a pilot program to demonstrate the potential for these products, although the results are so far fairly limited. While some forms of regulation can stymie innovation, they can also spur it either in the cat-and-mouse fashion of the regulatory dialectic as described by Kane (1981) or in the encouragement to pilot new ideas.

\section{Cast Study 4: Open-End Mutual Funds}

Mutual funds are collective investment vehicles in which large numbers of individual investors pools their resources under common management to invest in a diversified pool of assets. A distinguishing characteristic of open-end mutual funds is that investors are allowed to buy and redeem shares on a daily basis, at a price equal to the fund's calculated net asset value. In the absence of effective government oversight, mutual funds would suffer from potentially serious market failures. To evaluate the performance of funds, individual investors require extensive information that would be difficult to assemble and verify in the absence of assistance from fund management. In addition, mutual-fund disclosures are most useful if the disclosures are prepared in a common format that facilitates comparison across different mutual funds. Collective investment vehicles also suffer from numerous potential agency problems, in that management could face incentives to divert fund resources to benefit either management or preferred classes of shareholders in the absence of regulatory restrictions. In addition, investments with mutual fund tend to be long term commitments and investors risk opportunistic behavior on the part of fund management and other shareholders absent credible oversight and enforcement mechanisms. This litany of problems is not merely hypothetical: in the first half of the twentieth century, the mutual fund industry was plagued with many of these issues. (Jackson and Symons, 1999)

Unlike our other cases studies, mutual funds represent an area of consumer finance that has operated under a comprehensive and relatively stable system of supervisory oversight for more than half a century and has largely addressed the issues above. Indeed, the regulation of mutual funds in the United States offers a good example of overlapping (and arguably redundant) regulatory strategies to address an interconnected set of market failures. (Frankel and Kirsch, 2003; Coates, 2008) At the center of mutual fund regulation is the Securities and Exchange Commission (SEC) which enforces the Investment Company Act of 1940. This Act strictly regulates the structure of mutual funds, imposing severe restrictions on liabilities and complex

\footnotetext{
${ }^{39}$ Anecdotally, after a PDL interest rate cap was imposed in Ohio, lenders responded by disbursing loans as checks rather than cash and then charged separate check-cashing fees.
} 
capital structures, establishing elaborate rules for daily pricing of shares for sale and redemption, and setting significant diversification requirements for fund assets (supplemented through further diversification requirements effected through the internal revenue code). In addition to these stringent portfolio-shaping rules, the Act and implementing SEC regulations mandate that independent boards of directors police many aspects of fund business, especially transactions, like advisory contracts, where management could exploit investors through excessive fees. Further fiduciary duties are imposed on fund advisers and the securities firms that distribute mutual fund shares, and the amount of fund resources that can be spent on distribution activities are strictly constrained. In addition, extensive disclosure requirements are imposed on mutual funds (including both fund specific information and disclosure formats designed to facilitate comparison across funds) and a substantial private industry of rating systems and publications digest and interpret fund disclosures for the investing public. To monitor compliance with regulatory standards, SEC and FINRA staff members perform regular examinations of all mutual funds on a periodic basis and routinely bring and publicize enforcement actions against offending firms. Under a range of statutory provisions, private litigants can and do sue mutual fund companies and related parties for, among other things, misleading disclosures, excessive fees, or abusive sales practices. Finally, the Investment Company Institute and several other trade groups play important roles in developing best practices and conducting research relevant to industry participants. ${ }^{40}$

As a complex and highly visible example of government oversight, mutual fund regulation has over the years been subjected to a host of criticisms across a range of topics. ${ }^{41}$ Mutual fund disclosure requirements have been characterized as both insufficient and excessively burdensome. Fiduciary oversight from independent directors has been labeled both inadequately vigorous and needlessly intrusive, in particular in negotiating lower fees for investors. One area of concern has been the use of fund resources to finance the costs of distributing fund shares, a practice that gave rise to considerable litigation in the 1960's and 1970's and has subsequently been channeled into SEC-supervised but still controversial practices of allowing fund advisers to fund certain research activities with soft-dollar payments and the impose $12 \mathrm{~b}-1$ fees to cover distribution costs. And, scandals of the last decade involving market timing and late trading - practices whereby management firms allowed some shareholders to benefit from excessive or after-hours fund transactions at the expense of ordinary investors have raised questions as to whether existing supervisory safeguards were sufficient.

But the indisputable and overarching empirical fact about mutual funds has been their phenomenal growth over the last six decades. As of year-end 2009, U.S. mutual funds held more than $\$ 11$ trillion in assets, equivalent to over 77.5 percent of the 2009 GDP. ${ }^{42}$ By comparison, in

\footnotetext{
40 Money market mutual funds are subject to even more regulatory restrictions under SEC Rule 2a-7 and raise distinctive policy concerns, especially with respect to the level pricing that this rule permits.

41 For a somewhat dated but still useful overview of investment company regulation and potential areas of reform, see United States Securities and Exchange Commission Division of Investment Management (1992).

42 See Federal Reserve Statistical Release Z.1: Flow of Funds Account of the United States (Mar. 11, 2010) (http://www.federalreserve.gov/releases/z1/Current/z1.pdf, visited 5/4/2010).
} 
1950, the industry held only $\$ 2.5$ billion in assets, less than one percent of GDP at the time. (Jackson and Symons, 1999) As a fraction of household financial assets, mutual funds constituted less than one percent of household financial market assets in 1950, and has grown to more than 21 percent by year end 2009. (Investment Company Institute, 2010) Simplistically, some argue that regulation can foster innovation through regulatory arbitrage, or can inhibit it through restrictions: neither of these characterize the fund industry. Rather, the fund industry has seen extensive innovation in the number and types of funds despite extensive regulation. While a variety of factors no doubt contributed to this growth, many industry observers cite the role of effective regulatory oversight and supervision as critical to helping the industry overcome adverse public opinion arising out of abuses in the 1920's and 1930's and earning the confidence of the investing public in the latter half of the Twentieth Century. ${ }^{43}$ Recent evidence suggests that investor protection is an important part of the success of the US industry. In two studies of mutual funds across multiple countries, specific elements of fund investor protection were shown to be associated with fund growth, the share of primary assets held by funds, and lower fees. (Khorana, Servaes and Tufano 2005, 2009). After controlling for fund type, fund size, and other relevant variables, fund fees in the US were among the lowest in the world. More specifically, while some have argued that fund boards are insufficiently independent, a number of studies have found evidence that effective board structure is associated with lower fees, quicker resolution of poor performance through mergers, and greater vigilance with respect to market timing policing (e.g., Tufano and Sevick 1997, Khorana, Wedge and Tufano 2007, Zitzewitz 2003)

Notwithstanding this positive evidence, much academic and policy attentions has focused on the level and composition of mutual fund fees, most importantly the payments that management companies and their affiliate receive from fund assets. As mentioned earlier, a number of empirical studies have detected puzzling variation in the levels of fees imposed on indexed mutual funds that pursue identical investment strategies. (Hortacsu and Syverson, 2004) A large body of work has raised questions about the value of the generally higher fees paid for active management of mutual fund portfolios. (Swenson, 2005) And yet other studies have questioned the benefits to investors who purchase mutual fund shares through independent brokers, as opposed to direct sales from mutual fund companies. (Bergstresser, Chalmers and Tufano, 2009.) Collectively, these studies raise questions about the cognitive capacities of at least some investors to monitor fund fees effectively. More generally, some industry critics have questioned whether mutual fund shares have appropriately shared in the substantial economies of scale that the industry has achieved through its growth over the past several decades. (Freeman and Brown, 2001.) Other analysts have pointing to conflicting evidence suggesting that competitive pressures have exerted downward pressure on management fees, but upward pressure on distribution costs. (Coates and Hubbard, 2007).

\footnotetext{
43 Beyond this impressive rate of growth, the mutual fund industry often operating under SEC exemptive orders has made a number of major innovations in product design, including the money market mutual funds that offer a substitute for bank deposits, multi-class funds that allow funds to attract investments from different distribution channels, exchange traded funds that provide greater liquidity, and most recently target date funds that offer automatically rebalancing portfolios matched to the expected retirement date of investors. (Lerner and Tufano, 2009)
} 
The appropriate scope of mutual fund regulation is an issue of ongoing debate. One controversy concerns whether certain investment restrictions for money market mutual funds should be tightened - or be held to bank regulatory standards, but little question that regulation itself should be scaled back. (United States Securities and Exchange Commission, 2010.)In other developed countries, most collective investment vehicles are organized and regulated as UCITS (Undertakings for the Collective Investment of Transferrable Securities) a contractual structure that is much less heavily regulated than American mutual funds. A number of commentators have suggested that UCITS-style investment vehicles should also be available in the United States, to increase investor choice and provide competition for traditional mutual funds. (Coates, 2009; ICI, 2007; SEC Division of Investment Management, 1992) On the domestic side, the 1940 Act includes a number of exceptions that permit other forms of collective investment vehicles, most notably hedge funds and private equity funds, to operate under much less stringent regulations provided investors are marketed only to a small number of investors or those with substantial wealth. Analysts differ as to whether the narrowness of these exemptions are important safeguards for retail investors or unnecessary constraints on investment choice. (United States Securities and Exchange Commission, 2003.) Finally, some financial services firms -- for example, banks with collective trust funds and insurance companies with equity indexed annuities - offer products that are functionally similar to mutual funds, and experts differ whether the proliferation of functionally similar products under different legal requirements represents a beneficial form of legal innovation or a disruptive instance of regulatory arbitrage. (Coates, 2009)

\section{Conclusion}

In this paper we have described a number of rationales for regulatory intervention in consumer financial markets. Some of these relate to economists' traditional concerns about asymmetric information and imperfect contracting, others to a more recent appreciation for the limits of consumer rationality.

It is important, however, to keep in mind the limitations on the ability of regulation to improve financial outcomes for consumers. Politicians and regulators can easily do more harm than good if these limitations are ignored.

First, many consumer financial products are expensive to provide because of the small size of each consumer transaction. In the market for short-term consumer credit, for example, it is inevitable that small loans will be expensive unless they are organized through a long-term relationship that can amortize fixed costs over many related transactions. In such markets, APR ceilings therefore have the unintended effect of eliminating provision of one form of short-term credit and potentially forcing some consumer to rely on more expensive alternatives.

Second, there is important cross-sectional variation in the financial products that are suitable for different consumers. For example, homeowners who expect to move in the near future should not pay for the expensive refinancing option embedded in a long-term nominal fixed-rate mortgage. Similarly, payday loans may be helpful for certain consumers and harmful for others. Regulators should be cautious about imposing “one size fits all” solutions. 
Third, even in markets where commonly used financial products seem satisfactory, these products are often not perfect and can potentially be improved by financial innovation. In the market for retirement savings products, for example, even the best current investment solutions, such as lifecycle mutual funds, lack any mechanism for giving consumers access to less liquid asset classes that might earn them an illiquidity premium.

Fourth, regulation can easily have unintended consequences if market participants use financial innovation to circumvent clumsily designed or costly regulations. ${ }^{44}$ A leading example is the 1974 reform of defined benefit (DB) pension regulations which inadvertently encouraged the growth of the defined contribution (DC) retirement savings plans. DC plans do have some advantages relative to DB plans, for example, their greater portability as employees move from one job to the next; but they also impose a more substantial burden on households to self-manage their retirement savings, a responsibility many households appear ill-suited to bear. It is not clear that the current U.S. system has achieved an optimal balance between DC-like and DB-like retirement plans. In the case of payday lenders, the decision of regulators to exclude federally insured depository institutions from participating in payday lending may have served largely to move that activity to smaller, local firms that are both less efficient and more difficult to supervise.

Finally, all regulation is subject to the political process which can easily capture regulation and use it to achieve short-term political goals rather than the originally intended economic goals. It appears, for example, that politicians' desire to extend credit access to lower income households was a contributing factor in the development of the subprime mortgage market, the recent housing and credit bubbles, and ultimately the financial crisis of 2007-09.

Given these potential problems, any regulatory agency, including the new Bureau of Consumer Financial Protection should follow a disciplined process when considering new financial regulations. The first step must be to identify specific problems such as those we discussed in section III and in our case study. The second step is to design metrics for success in addressing these problems. For example, if the problem is the wide dispersion in the fees that consumers pay for extremely similar products such as index mutual funds, metrics for success could include an increase in consumer knowledge of available low-cost options, or a decrease in the dispersion of fees that consumers actually pay. The third step is to tailor interventions to the problems at hand, taking into account the wide range of regulatory mechanisms and combination of mechanisms potentially available The fourth step is to implement research to determine whether candidate interventions actually can deliver improvements in the metrics for success from the second step.

This last step is a substantial challenge in itself, and will require a broad array of research methodologies. Some evidence can be gathered from aggregate data, for example, in measuring the adequacy of retirement saving from statistics on the participation rate in 401(k) plans. This

\footnotetext{
${ }^{44}$ The fragmented structure of the U.S. system of financial oversight and the capacity of firms to use different legal forms to provide similar financial functions create additional opportunities for regulatory arbitrage on the part of the financial services industry (Jackson, 1999).
} 
type of work requires careful attention to possible crowding out effects, for example shifts from fully taxable to tax-favored retirement saving or movement from payday lenders to other sources of short term credit. Other evidence can come from cross-country comparisons.

But aggregate research alone is unlikely to be sufficient. There is an urgent need for improved experimental data on consumer responses to and understanding of new financial products, and household-level field data to reveal cross-sectional variation in financial decision making. Most household-level field research uses surveys, such as the Federal Reserve's Survey of Consumer Finances, but these surveys have severe limitations including refusals to participate (particularly among the wealthy), limited granularity, and inaccurate responses. In the future it will be important to gather accurate household-level data from a wide array of financial service providers. Such data will be much more useful if they can be merged into a comprehensive package that describes the complete financial position of households, and more useful still if they can be linked with survey data on households' beliefs, stated objectives, and financial literacy. 
TABLE 1. Financial Holdings of U.S. Families in 2007

\begin{tabular}{|c|c|c|c|c|c|c|c|c|c|c|c|}
\hline $\begin{array}{l}\text { Family } \\
\text { characteristic }\end{array}$ & $\begin{array}{c}\text { Transaction } \\
\text { accounts }\end{array}$ & $\begin{array}{c}\text { Certificates } \\
\text { of deposit }\end{array}$ & $\begin{array}{c}\text { Savings } \\
\text { bonds }\end{array}$ & Bonds & Stocks & $\begin{array}{c}\text { Pooled } \\
\text { investment } \\
\text { funds }\end{array}$ & $\begin{array}{c}\text { Retirement } \\
\text { accounts }\end{array}$ & $\begin{array}{c}\text { Cash } \\
\text { value life } \\
\text { insurance }\end{array}$ & $\begin{array}{c}\text { Other } \\
\text { managed } \\
\text { assets }\end{array}$ & Other & $\begin{array}{c}\text { Any } \\
\text { financial } \\
\text { asset }\end{array}$ \\
\hline & \multicolumn{11}{|c|}{ Percentage of families holding asset } \\
\hline All families & $92.1 \%$ & $16.1 \%$ & $14.9 \%$ & $1.6 \%$ & $17.9 \%$ & $11.4 \%$ & $52.6 \%$ & $23.0 \%$ & $5.8 \%$ & $9.3 \%$ & $93.9 \%$ \\
\hline \multicolumn{12}{|l|}{$\begin{array}{l}\text { By income } \\
\text { percentile }\end{array}$} \\
\hline$<20$ & 74.9 & 9.4 & 3.6 & -- & 5.5 & 3.4 & 10.7 & 12.8 & 2.7 & 6.6 & 79.1 \\
\hline 20 to $<40$ & 90.1 & 12.7 & 8.5 & -- & 7.8 & 4.6 & 35.6 & 16.4 & 4.7 & 8.8 & 93.2 \\
\hline 40 to $<60$ & 96.4 & 15.4 & 15.2 & -- & 14.0 & 7.1 & 55.2 & 21.6 & 5.3 & 10.2 & 97.2 \\
\hline 60 to $<80$ & 99.3 & 19.3 & 20.9 & 1.4 & 23.2 & 14.6 & 73.3 & 29.4 & 5.7 & 8.4 & 99.7 \\
\hline 80 to $<90$ & 100.0 & 19.9 & 26.2 & 1.8 & 30.5 & 18.9 & 86.7 & 30.6 & 7.6 & 9.8 & 100.0 \\
\hline \multirow[t]{2}{*}{90 to $<100$} & 100.0 & 27.7 & 26.1 & 8.9 & 47.5 & 35.5 & 89.6 & 38.9 & 13.6 & 15.3 & 100.0 \\
\hline & \multicolumn{11}{|c|}{ Median value of holdings for families holding asset (\$1000s) } \\
\hline All families & $\$ 4.0$ & $\$ 20.0$ & $\$ 1.0$ & $\$ 80.0$ & $\$ 17.0$ & $\$ 56.0$ & $\$ 45.0$ & $\$ 8.0$ & $\$ 70.0$ & $\$ 6.0$ & $\$ 28.8$ \\
\hline \multicolumn{12}{|l|}{$\begin{array}{l}\text { By income } \\
\text { percentile }\end{array}$} \\
\hline$<20$ & .8 & 18.0 & .5 & -- & 3.8 & 30.0 & 6.5 & 2.5 & 100.0 & 1.5 & 1.7 \\
\hline 20 to $<40$ & 1.6 & 18.0 & 1.0 & -- & 10.0 & 30.0 & 12.0 & 5.0 & 86.0 & 3.0 & 7.0 \\
\hline 40 to $<60$ & 2.7 & 17.0 & .7 & -- & 5.5 & 37.5 & 23.9 & 5.2 & 59.0 & 4.0 & 18.6 \\
\hline 60 to $<80$ & 6.0 & 11.0 & 1.0 & 19.0 & 14.0 & 35.0 & 48.0 & 10.0 & 52.0 & 10.0 & 58.3 \\
\hline 80 to $<90$ & 12.9 & 20.0 & 2.0 & 81.0 & 15.0 & 46.0 & 85.0 & 9.0 & 30.0 & 10.0 & 129.9 \\
\hline 90 to $<100$ & 36.7 & 42.0 & 2.5 & 250.0 & 75.0 & 180.0 & 200.0 & 28.1 & 90.0 & 45.0 & 404.5 \\
\hline
\end{tabular}


TABLE 2. Financial Liabilities of U.S. Families in 2007

\begin{tabular}{|c|c|c|c|c|c|c|c|}
\hline \multirow{2}{*}{$\begin{array}{l}\text { Family } \\
\text { characteristic }\end{array}$} & \multicolumn{2}{|c|}{ Secured by residential property } & \multirow{2}{*}{$\begin{array}{c}\text { Installment } \\
\text { loans }\end{array}$} & & \multirow{2}{*}{$\begin{array}{l}\text { Lines of credit } \\
\text { not secured by } \\
\text { residential } \\
\text { property }\end{array}$} & \multirow[b]{2}{*}{ Other } & \multirow[b]{2}{*}{ Any debt } \\
\hline & $\begin{array}{l}\text { Primary } \\
\text { residence }\end{array}$ & Other & & balances & & & \\
\hline & \multicolumn{7}{|c|}{ Percentage of families holding debt } \\
\hline All families & $48.7 \%$ & $5.5 \%$ & $46.9 \%$ & $46.1 \%$ & $1.7 \%$ & $6.8 \%$ & $77.0 \%$ \\
\hline \multicolumn{8}{|c|}{ By income percentile } \\
\hline$<20$ & 14.9 & 1.1 & 27.8 & 25.7 & $\stackrel{*}{-}$ & 3.9 & 51.7 \\
\hline 20 to $<40$ & 29.5 & 1.9 & 42.3 & 39.4 & 1.8 & 6.8 & 70.2 \\
\hline 40 to $<60$ & 50.5 & 2.6 & 54.0 & 54.9 & $*$ & 6.4 & 83.8 \\
\hline 60 to $<80$ & 69.7 & 6.8 & 59.2 & 62.1 & 2.1 & 8.7 & 90.9 \\
\hline 80 to $<90$ & 80.8 & 8.5 & 57.4 & 55.8 & $*$ & 9.6 & 89.6 \\
\hline \multirow[t]{2}{*}{90 to $<100$} & 76.4 & 21.9 & 45.0 & 40.6 & 2.1 & 7.0 & 87.6 \\
\hline & \multicolumn{7}{|c|}{ Median value of debt for families holding debt (\$1000s) } \\
\hline All families & $\$ 107.0$ & $\$ 100.0$ & $\$ 13.0$ & $\$ 3.0$ & $\$ 3.8$ & $\$ 5.0$ & $\$ 67.3$ \\
\hline \multicolumn{8}{|c|}{ By income percentile } \\
\hline$<20$ & 40.0 & 70.0 & 6.5 & 1.0 & -- & 3.0 & 9.0 \\
\hline 20 to $<40$ & 51.0 & 42.0 & 9.8 & 1.8 & 1.3 & 4.0 & 18.0 \\
\hline 40 to $<60$ & 88.7 & 68.9 & 12.8 & 2.4 & -- & 4.0 & 54.5 \\
\hline 60 to $<80$ & 115.0 & 83.0 & 16.3 & 4.0 & 5.1 & 5.3 & 111.3 \\
\hline 80 to $<90$ & 164.0 & 125.0 & 17.3 & 5.5 & -- & 5.0 & 182.2 \\
\hline 90 to $<100$ & 201.0 & 147.5 & 18.3 & 7.5 & 17.3 & 7.5 & 235.0 \\
\hline
\end{tabular}


TABLE 3. Individual Financial Literacy

\begin{tabular}{|c|c|c|c|c|c|c|}
\hline \multirow[b]{2}{*}{ Financial Literacy Question } & \multicolumn{3}{|c|}{$\begin{array}{c}\text { Health and Retirement } \\
\text { Study } 2004 \\
\text { (Respondents largely aged 50-69) } \\
\end{array}$} & \multicolumn{3}{|c|}{$\begin{array}{c}\text { National Longitudinal Survey of } \\
\text { Youth 2007-2008 } \\
\text { (Respondents aged 23-28) } \\
\end{array}$} \\
\hline & Correct & Incorrect & $\begin{array}{l}\text { Don’t know } \\
\text { or refused }\end{array}$ & Correct & Incorrect & $\begin{array}{c}\text { Don’t know } \\
\text { or refused }\end{array}$ \\
\hline $\begin{array}{l}\text { Suppose you had } \$ 100 \text { in a savings account and the interest rate was } \\
2 \% \text { per year. After } 5 \text { years, how much do you think you would have } \\
\text { in the account if you left the money to grow: more than } \$ 102 \text {, } \\
\text { exactly } \$ 102 \text {, less than } \$ 102 \text { ? }\end{array}$ & 67.1 & 22.2 & 10.7 & 79.5 & 14.6 & 5.7 \\
\hline $\begin{array}{l}\text { Imagine that the interest rate on your savings account was } 1 \% \text { per } \\
\text { year and inflation was } 2 \% \text { per year. After } 1 \text { year, would you be able } \\
\text { to buy more than, exactly the same as, or less than today with the } \\
\text { money in this account? }\end{array}$ & 75.2 & 13.4 & 10.4 & 54.0 & 30.7 & 15.1 \\
\hline $\begin{array}{l}\text { Do you think that the following statement is true or false? "Buying a } \\
\text { single company stock usually provides a safer return than a stock } \\
\text { mutual fund." }\end{array}$ & 52.3 & 13.2 & 34.6 & 46.8 & 15.8 & 37.3 \\
\hline
\end{tabular}

Source: Columns 1-3, Lusardi and Mitchell (2006); Columns 4-6, Lusardi, Mitchell and Curto (2010). 


\section{References}

Agarwal, Anup, and Mark A. Chen. 2008. "Do Analyst Conflicts Matter? Evidence from Stock Recommendations.” The Journal of Law and Economics 51(3):503-537.

Agarwal, Sumit, John C. Driscoll, Xavier Gabaix, and David Laibson. 2009. "The Age of Reason: Financial Decisions over the Life Cycle and Implications for Regulation.” Brookings Papers on Economic Activity (Fall).

Agarwal, Sumit; Paige Skiba and Jeremy Tobacman. 2009. "Payday Loans and Credit Cards: New Liquidity and Credit Scoring Puzzles?," In Available at SSRN: http://ssrn.com/abstract $=1327125$.

Aguiar, Mark, and Erik Hurst. 2007. “Life-Cycle Prices and Production.” American Economic Review 97(5):1533-1559.

Ameriks, John and Stephen P. Zeldes. 2004. "How do Household Portfolio Shares Vary with Age?” Columbia University Working Paper.

Bair, Sheila. 2005. "Low-Cost Payday Loans: Opportunities and Obstacles," In. Annie E. Casey Foundation.

Bar-Gill, Oren. 2008. “The Behavorial Economics of Consumer Contracts.” Minnesota Law Review, 92:749-802.

Barr, Michael S., Sendhil Mullainathan, and Eldar Shafir. 2008. "Behaviorally Informed Financial Services Regulation.” New America Foundation,

Benartzi, Shlomo. 2001. "Excessive Extrapolation and the Allocation of 401(k) Accounts to Company Stock?" Journal of Finance, 56(5):1747-1764.

Benartzi, Shlomo and Richard H. Thaler. 2001. "Naive Diversification Strategies in Retirement Saving Plans.” American Economic Review 91(1): 79-98.

Benjamin, Daniel J., Sebastian A. Brown, and Jesse M. Shapiro. 2006. "Who is ‘Behavioral'? Cognitive Ability and Anomalous Preferences.” Unpublished paper, Harvard University and University of Chicago.

Bergstresser, Daniel, John Chalmers and Peter Tufano. 2009. "Assessing the Costs and Benefits of Brokers: A Preliminary Analysis of the Mutual Fund Industry," Review of Financial Studies 22 (October 2009) 4129 - 4156.

Bertrand, Marianne and Adair Morse. 2009. "Information Disclosure, Cognitive Biases and Payday Borrowing," Chicago Booth Research Paper No. 10-01. 
Bittker, Boris I., and Lawrence Lokken. 1999. Federal Taxation of Income, Estates and Gifts. Warren, Gorham \& Lamont.

Brown, Jeffrey R., Nellie Liang, and Scott Weisbenner. 2007. "Individual Account Investment Options and Portfolio Choice: Behavioral Lessons from 401(k) Plans.” Journal of Public Economics 91(10):1992-2013.

Bucks, Brian K., Arthur B. Kennickell, Traci L. Mach and Kevin B. Moore. 2009. "Changes in U.S. Family Finances from 2004 to 2007: Evidence from the Survey of Consumer Finances.” Federal Reserve Bulletin 95. http://www.federalreserve.gov/pubs/bulletin/2009/articles/scf/default.htm\#nl5 (accessed January 30, 2010).

Bucks, Brian K. and Karen M. Pence. 2008. “Do Borrowers Know Their Mortgage Terms?” Journal of Urban Economics 64:218-233.

Campbell, Dennis; Asis Martinez-Jerez and Peter Tufano. 2008. "Bouncing Out of the Banking System: An Empirical Analysis of Involuntary Bank Account Closures," http://www.bos.frb.org/economic/cprc/conferences/payments2008/campbell_jerez_tufano.pdf

Campbell, John Y. 2006. “Household Finance.” Journal of Finance 61(x):1553-1604.

Campbell, John Y. and Joao Cocco. 2003. "Household Risk Management and Optimal Mortgage Choice.” Quarterly Journal of Economics 118:1449-1494.

Campbell, John Y., Stefano Giglio, and Parag Pathak. 2009. "Forced Sales and House Prices.” National Bureau of Economic Research Working Paper 14866.

Carlin, Bruce I. and Simon Gervais. 2009. "Legal Protection in Retail Financial Markets.” NBER Working Paper No. w14972. Available at SSRN: http://ssrn.com/abstract=1408892.

Carrell, Scott and Jonathan Zinman. 2008. "In Harm's Way? Payday Loan Access and Military Personnel Performance," http://www.dartmouth.edu/ jzinman/Papers/PayDay_AirForce_aug08.pdf

Carroll, Gabriel D., James J. Choi, David Laibson, Andrew Metrick and Brigitte C. Madrian. 2009. “Optimal Defaults and Active Decisions.” Quarterly Journal of Economics

Caskey, John. 2002. "The Economics of Payday Lending," In. Madison, WI: Filene Research Institute.

. 1994. Fringe Banking: Check-Cashing Outlets, Pawnshops, and the Poor. New York: Russell Sage Foundation. . 2001. "Payday Lending." Financial Counseling and Planning, 12(2), pp. 1-14. 
CFSA, 2006, "National Data on Short-Term Credit Alternatives" http://www.cfsa.net/downloads/National_Data_on_Short_Term_Credit_Alternatives.pdf.

Choi, James J., David Laibson, Brigitte C. Madrian and Andrew Metrick. 2004. "Employees' Investment Decisions About Company Stock," Pension Design and Structure: New Lessons from Behavioral Finance, Olivia S. Mitchell and Stephen P. Utkus, editors.

Choi, James J., David Laibson, Brigitte C. Madrian and Andrew Metrick. 2004. "For Better or For Worse: Default Effects and 401(k) Savings Behavior," Perspectives in the Economics of Aging, David A. Wise, editor, 2004.

Choi, James J., David Laibson, Brigitte C. Madrian and Andrew Metrick. 2009. "Reinforcement Learning and Savings Behavior," Journal of Finance, 44(6): 2515-34.

Choi, James J., David Laibson and Brigitte C. Madrian. 2005. "Are Empowerment and Education Enough? Underdiversification in 401(k) Plans." Brookings Papers on Economic Activity.

Choi, James J., David Laibson and Brigitte C. Madrian. 2009. “\$100 Bills on the Sidewalk: Suboptimal Investment in 401(k) Plans.” Working Paper.

Choi, James J., David Laibson, and Brigitte C. Madrian. 2005. "\$100 Bills on the Sidewalk: Violations of No-Arbitrage in 401(k) Plans.” National Bureau of Economic Research Working Paper 11554.

Coates, John C. 2009. "Reforming the Taxation and Regulation of Mutual Funds." Journal of Legal Analysis 1(2): 591-689.

Coates, John C., and R. Glenn Hubbard. 2007. "Competition and Shareholder Fees in the Mutual Fund Industry: Evidence and Implications for Policy." Journal of Corporation Law, 33:151-222.

Cole, Shawn, and Gauri Kartini Shastry. 2009. "If You Are So Smart, Why Aren’t You Rich? The Effects of Education, Financial Literacy, and Cognitive Ability on Financial Market Participation.” Harvard Business School Working Paper 09-071.

Cole, Shawn; John Thompson and Peter Tufano. 2008. "Where Does It Go? Spending by the Financially Constrained," In. Harvard Business School Working Paper 08-083.

Consumer Reports, 2005. "False Security Check-Bounce Protection," Volume 70 (5), 45.

Crane, Dwight B. et al. 1995. The Global Financial System: A Functional Perspective. Boston, MA: Harvard Business Press.

Christelis, Dimitris, Tullio Jappelli, and Mario Padula. 2009. "Cognitive Abilities and Portfolio Choice.” Forthcoming European Economic Review. 
CRL Issue Brief, 2009, “APR Matters on Payday Loans” Durham, NC: Center for Responsible Lending.

CRL Research Brief, 2009. "Congress Should Cap Interest Rates," Durham, NC: Center for Responsible Lending.

Department of Labor, Employee Benefit Security Administration (2008), "Private Pension Plan Bulletin Historical Tables." http://www.dol.gov/ebsa/pdf/privatepensionplanbulletinhistoricaltables.pdf (accessed February 8, 2010).

Department of Labor, Employee Benefit Security Administration (2010), "Private Pension Plan Bulletin: Abstract of 2007 Form 5500 Annual Reports.” http://www.dol.gov/ebsa/pdf/2007pensionplanbulletin.pdf (accessed February 8, 2010).

Department of Treasury. 2009. Financial Regulatory Reform: A New Foundation. Washington, D.C.

DeYoung, Robert and Ronnie J. Phillips. 2009. "Payday Loan Pricing," Federal Reserve Bank of Kansaas City Economic Research Department.

Elliehausen, Gregory. 2009. "An Analysis of Consumers' Use of Payday Loans," In Financial Services Research Program, Monograph No. 41. Washington, DC: George Washington University School of Business.

Elliehausen, Gregory and Edward C. Lawrence. 2001. "Payday Advance Credit in America: An Analysis of Consumer Demand," In. Washington, DC: Credit Research Center, McDonough School of Business, Georgetown University.

Engelhardt, Gary and Anil Kumar. Forthcoming. "Pensions and Household Wealth Accumulation.” Journal of Human Resources

Federal Deposit Insurance Corporation. 2009. FDIC National Survey of Unbanked and Underbanked Households. Washington, D.C.

Fidelity Investments. 2009. “Evaluating Auto Solutions.” Fidelity Perspectives, Summer 2009.

Flannery, Mark and Katherine Samolyk. 2005. "Payday Lending: Do the Costs Justify the Price?," In Center for Financial Research Working Paper. Washington, DC: FDIC.

Foote, Christopher, Kristopher Gerardi, Lorenz Goette, and Paul Willen. 2010. "Reducing Foreclosures.” Forthcoming in NBER Macroeconomics Annual 2009.

Fox, Jean Anne and Patrick Woodall. 2006. "Cashed Out: Consumers Pay Steep Premium to "Bank" at Check Cashing Outlets," Washington, DC: Consumer Federation of America. 
Frankel, Tamar and Clifford E. Kirsch. 2003. Investment Management Regulation (2 ${ }^{\text {nd }}$ Edition). Fathom Publishing Co.: Anchorage, Alaska.

Freeman, John P., and Stewart L. Brown. 2001. "Mutual Fund Advisory Fees: The Costs of Conflicts of Interest.” Journal of Corporate Law, 26:609-674.

Gabaix, Xavier, and David Laibson. 2006. "Shrouded Attributes, Consumer Myopia, and Information Suppression in Competitive Markets.” Quarterly Journal of Economics 121(2):505540 .

Ghilarducci, Teresa. 2008. "When I'm Sixty-Four: The Plot against Pensions and the Plan to Save Them.” Princeton University Press.

Government Accountability Office. 2009. Financial Regulation: A Framework for Crafting and Assessing Proposals to Modernize the Outdated U.S. Financial Regulatory System (January 8, 2009) (GAO-09-216).

Graves, Stephen M. 2003. "Landscapes of Predation, Landscapes of Neglect: A Locational Analysis of Payday Lenders and Banks." The Professional Geographer, 55(3), pp. 303-17.

Greenspan, Alan. 2004. "Understanding Household Debt Obligations.” Speech to Credit Union National Association 2004 Governmental Affairs Conference, Washington, DC. Available online at http://www.federalreserve.gov/boarddocs/speeches/2004/20040223/

Grinblatt, Mark, Matti Keloharju, and Juhani Linnainmaa. 2009. "Do Smart Investors Outperform Dumb Investors?” University of Chicago Center for Research in Security Prices Working Paper 09-33.

Guiso, Luigi, Paola Sapienza, and Luigi Zingales. 2008. “Trusting the Stock Market." Journal of Finance 63(6):2557-2600.

Gustman, Alan L., Thomas L. Steinmeier, and Nahid Tabatabai. 2010. "What the Stock Market Decline Means for the Financial Security and Retirement Choices of the Near-Retirement Population.” Journal of Economic Perspectives 24(1):1-22.

Hillman, Richard J. 2009. "Financial Literacy and Education Commission: Progress Made in Fostering Partnerships, but National Strategy Remains Largely Descriptive Rather Than Strategic.” (April 29, 2009) (GAO-09-638T).

Hortacsu, Ali, and Chad Syverson. 2004. "Product Differentiation, Search Costs, and Competition in the Mutual Fund Industry: A Case Study of S\&P 500 Index Funds.” Quarterly Journal of Economics 119(2):403-456.

Huckstep, Aaron. 2007. "Payday Lending: Do Outrageous Prices Necessarily Mean Outrageous Profits?" Fordham Journal of Corporate and Financial Law, XII, pp. 203-31. 
Inderst, Roman, and Marco Ottaviani. 2009. "Misselling through Agents." American Economic Review, 99(3): 883-908.

Investment Company Institute. 2007. Review of the Regulatory Structure Associated with Financial Institutions. Submission to the Department of the Treasury. http://www.ici.org/policy/comments/07_treas_reg_structure_com\#g.

Investment Company Institute. 2010 Investment Company Fact Book. Avail. at http://www.ici.org/pdf/2010 factbook.pdf.

Iwry, J. Mark and David C. John. 2009. "Pursuing Universal Retirement Security Through Automatic IRAs.” The Retirement Security Project, Washington D.C.

Jackson, Howell E. 1999. "Regulation of a Multisectored Financial Services Industry: An Exploratory Essay.” Washington University Law Quarterly 77:319.

Jackson, Howell E. 2007. "Variation in the Intensity of Financial Regulation: Preliminary Evidence and Potential Implications. Yale Journal on Regulation 24:253.

Jackson, Howell E. 2008. “The Trilateral Dilemma in Financial Regulation.” In Overcoming the Savings Slump: How to Increase the Effectiveness of Financial Education and Savings Programs, ed. Annamaria Lusardi, Chap. 3. Chicago, IL: University of Chicago Press.

Jackson, Howell E. and Edward L. Symons. 1999. The Regulation of Financial Institutions: Cases and Materials. St. Paul, MN: West Publications.

Jackson, Howell E. and Laurie Burlingame. "Kickbacks or Compensation: The Case of Yield Spread Premiums.” Stanford Journal of Law, Business and Finance 12:289.

Jacoby, Melissa B. 2010. “Making Debtor Remedies More Effective.” Available at SSRN: http://papers.ssrn.com/sol3/papers.cfm?abstract_id=1550964.

Kane, Edward J. 1981. "Accelerating Inflation, Technological Innovation, and the Decreasing Effectiveness of Banking Regulation." Journal of Finance, 36(May), pp. 355-67.

Khandani, Amir E., Andrew W. Lo, and Robert C. Merton. 2009. "Systemic Risk and the Refinancing Ratchet Effect.” National Bureau of Economic Research Working Paper 15362.

Khorana, Ajay, Henri Servaes and Peter Tufano. 2009. Mutual Fund Fees Around the World," Review of Financial Studies 22 (March 2009) 1279 - 1310.

Khorana, Ajay, Peter Tufano, and Lei Wedge. 2007. "Board Structure, Mergers and Shareholder Wealth: A Study of the Mutual Fund Industry," Journal of Financial Economics 85, 2 (August 2007), 571-598. 
Khorana, Ajay, Henri Servaes and Peter Tufano. 2009. "Explaining the Size of The Mutual Fund Industry Around the World,", Journal of Financial Economics 78 (October 2005), 145185.

Kimball, Miles S. and Tyler Shumway. 2007. "Investor Sophistication and the Home Bias, Diversification, and Employer Stock Puzzles.” Unpublished paper, University of Michigan.

King, Uriah; Leslie Parrish and Ozlem Tanik. 2006. "Financial Quicksand" Durham, NC: Center for Reponsible Lending.

Laibson, David. 1997. “Golden Eggs and Hyperbolic Discounting.” Quarterly Journal of Economics 112:443-477.

Langbein, John H. 1995. “The Contractarian Basis of the Law of Trusts.” Yale Law Journal 105:624.

Laurent E. Calvet, John Y. Campbell and Paolo Sodini. 2007. "Down or Out: Assessing the Welfare Costs of Household Investment Mistakes.” Journal of Political Economy 115(5):707747.

Laurent E. Calvet, John Y. Campbell and Paolo Sodini. 2009. "Fight or Flight? Portfolio Rebalancing by Individual Investors" Quarterly Journal of Economics, February 2009

Lawrence, Edward C. and Gregory Elliehausen. 2008. "A Comparative Analysis of Payday Loan Customers." Contemporary Economic Policy, 26(2), pp. 299.

Lehman, Thomas E. 2005. "Contrasting Payday Loans to Bounced-Check Fees," In. Washington, DC: Consumer Credit Research Foundation.

Lusardi, Annamaria, and Olivia Mitchell. 2007a. "Baby Boomer Retirement Security: The Roles of Planning, Financial Literacy, and Housing Wealth.” Journal of Monetary Economics 54(1):205-224.

Lerner, Josh, and Peter Tufano. 2009. The Consequences of Financial Innovation: A Research Agenda. Unpublished paper, Harvard Business School.

Lusardi, Annamaria and Olivia S. Mitchell. 2006. "Financial Literacy and Planning: Implications for Retirement Well-Being.” Pension Research Council Working Paper No. 1.

Lusardi, Annamaria, and Olivia Mitchell. 2007b. "Financial Literacy and Retirement Preparedness: Evidence and Implications for Financial Education.” Business Economics 42(1): 35-44.

Lusardi, Annamaria and Peter Tufano. 2009. "Debt Literacy, Financial Experiences, and Overindebtedness." NBER Working Paper Series, w. 14808. 
Lusardi, Annamaria, Olivia S. Mitchell and Vilsa Curto. 2010. "Financial Literacy among the Young: Evidence and Implications for Consumer Policy.” Working Paper.

Mann, Ronald J. and Jim Hawkins. 2007. "Just until Payday." UCLA Law Review ’, 54(855).

Melzer, Brian T. 2009. "The Real Costs of Credit Access: Evidence from the Payday Lending Market," In. Evanston, IL: Kellogg School of Management, Northwestern University.

Merton, Robert C. and Zvi Bodie. 1995. “A Conceptual Framework for Analyzing the Financial Environment.” In The Global Financial System: A Functional Perspective, ed. D.B. Crane et al, chap. 1. Boston, MA: Harvard Business Press.

Miles, David. 2003. The UK Mortgage Market: Taking A Longer-Term View, Interim Report: Information, Incentives, and Pricing. London: HM Treasury.

Mitchell, Olivia S., Gary Mottola, Steve Utkus, and Takeshi Yamaguchi. 2006. "The Inattentive Participant: Trading Behavior in 401(k) Plans.” Pension Research Council Working Paper.

Morgan, Donald P. and Michael R. Strain. 2008. "Payday Holiday: How Households Fare after Payday Credit Bans," In Staff Report no. 309. Federal Reserve Bank of New York.

Morse, Adair. 2009. "Payday Lenders: Heroes or Villains?," http://faculty.chicagobooth.edu/adair.morse/research/Morse_paydayDisaster.pdf

Park, Youngkyun. 2009. "Investment Behavior of Target-Date Fund Users Having Other Funds in 401(k) Plan Accounts.” Employee Benefit Research Institutes Notes, 30(12).

Parrish, Leslie. 2008. "High Cost Payday Lending Traps Arizona Borrowers," Durham, NC: Center for Responsible Lending.

Peterson, Christopher L. 2008. "Usury Law, Payday Loans, and Statutory Sleight of Hand: Salience Distortion in American Credit Pricing Limits.” Minnesota Law Review. 92:1110.

Schiltz, Elizabeth R. 2004. “The Amazing, Elastic, Ever-Expanding Exportation Doctrine and Its Effect on Predatory Lending Regulation.” Minnesota Law Review 88:518.

Schurter. 2008. "An Experimental Analysis of the Demand for Payday Loans." Available at SSRN: http://ssrn.com/abstract=1083796.

Shiller, Robert J. 2008. The Subprime Solution: How Today's Global Financial Crisis Happened, and What to Do About It. Princeton, NJ: Princeton University Press.

Skiba, Paige and Jeremy Tobacman. 2009. "Do Payday Loans Cause Bankruptcy?" Available at SSRN: http://ssrn.com/abstract $=1266215$. 
. 2007. "The Profitability of Payday Loans," Philadelphia, PA: The Wharton School, University of Pennsylvania.

Smale, Pamela. 2005. "Payday Loans: Federal Regulatory Initiatives” (Congressional Research Service Report CR21728.)

Stango, Victor, and Jonathan Zinman. 2009. "Exponential Growth Bias and Household Finance.” Journal of Finance 64(6):2807-2849.

Stegman, Michael A. 2007. "Payday Lending." Journal of Economic Perspectives, 21(1), pp. $169-90$.

Stegman, Michael A. and Robert Faris. 2003. "Payday Lending: A Business Model That Encourages Chronic Borrowing." Economic Development Quarterly, 17(1), pp. 8-32.

Stigler, George J. 1971. "The Theory of Economic Regulation.” Bell Journal of Economics and Management Science 3:3-18.

Stoianovici, Petru S. and Michael T. Maloney. 2008. "Restrictions on Credit: A Public Policy Analysis of Payday Lending." Available at SSRN: http://ssrn.com/abstract=1291278.

Strotz, R.H. 1955. “Myopia and Inconsistency in Dynamic Utility Maximization.” Review of Economic Studies 23(3):165-180.

Swenson, David. 2005. Unconventional Success: A Fundamental Approach to Personal Investing. Free Press.

Swire, Peter P. 2003. "The Surprising Virtues of the New Financial Privacy Law.” Minnesota Law Review 86:1263.

Teplin, Albert M. 2001. "The US Flow-of-Funds Accounts and their Uses”, Federal Reserve Bulletin, July, 431-441.

Thaler, Richard H. and Cass Sunstein. 2008. Nudge: Improving Decisions About Health, Wealth, and Happiness. New Haven, CT: Yale University Press.

Thaler, Richard H. and Shlomo Benartzi. 2004. "Save More Tomorrow: Using Behavioral Economics to Increase Employee Savings." Journal of Political Economy, 112(1, Part 2): S164S187.

Tufano, Peter. 2009. “Consumer Finance.” Annual Review of Financial Economics 1:227-247.

Tufano, Peter and Andrea Ryan. 2009. "Blue Ocean or Stormy Waters? Buying Nix Check Cashing" " Harvard Business School Case, 210-012. 
Tufano, Peter and Matthew Sevick, 1997, "Board Structure and Fee-Setting in the U.S. Mutual Fund Industry," Journal of Financial Economics 46 (December 1997), 321-356.

United States Securities and Exchange Commission. 2010. Final Rule on Money Market Reform, Release IC-29132. Available at http://www.sec.gov/rules/final/2010/ic-29132.pdf.

United States Securities and Exchange Commission. 2003. Staff Report on Implications of the Growth of Hedge Funds. Avail. at http://www.sec.gov/news/studies/hedgefunds0903.pdf.

United States Securities and Exchange Commission Division of Investment Management. 1992. Protecting Investors: A Half Century of Investment Company Regulation. Available at http://www.sec.gov/divisions/investment/guidance/icreg50-92.pdf.

White, Michelle J. 2009. "Bankruptcy: Past Puzzles, Recent Reforms, and the Mortgage Crisis.” American Law and Economics Review, 11:1-23.

Wilson, Bart; David W. Findlay; James W. Meehan; Charissa P. Wellford and Karl

Schurter. 2010. "An Experimental Analysis of the Demand for Payday Loans." Available at SSRN: http://ssrn.com/abstract=1083796.

Woodward, Susan E. 2004. “Consumer Confusion in the Mortgage Market.” Sand Hill Econometrics Working Paper, available online at http://www.sandhillecon.com/pdf/consumer_confusion.pdf

Wright, Joshua D. 2007. "Behavioral Law and Economics, Paternalism, and Consumer Contracts: An Empirical Perspective.” NYU Journal of Law \& Liberty, 2:470-511.

Zelizer, Viviana A. (1994). The Social Meaning of Money: Pin Money, Paychecks, Poor Relief, and Other Currencies. Basic Books.

Zinman, Jonathan. 2008. "Restricting Consumer Credit Access: Household Survey Evidence on Effects around the Oregon Rate Cap," Working Paper No. 08-32. Philadelphia: Research Department, Federal Reserve Bank of Philadelphia. 